\title{
موقف الحافظ ابن أبي جمرة من التصوف
}

إعلاد

الدكتور / عبدالرؤف محمود عبدالرؤف

مدرس العقيدةوالفلسفتبكلي:أصول الدين والدعوةالإسلاميزبطنط) 


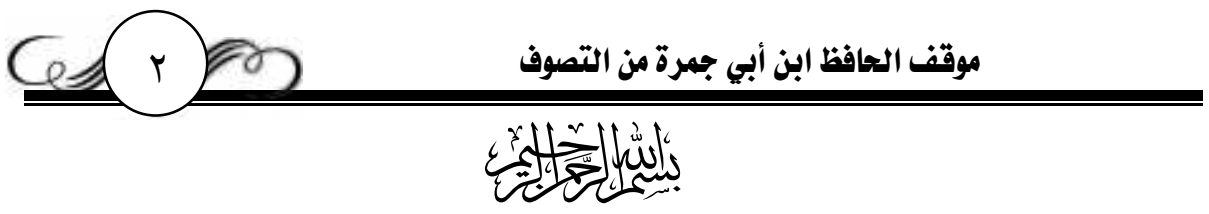

الحمد لله رب العالمين ، الذي بيده الأمر وهو على كل شيء قدير ـ و الصلاة

والسلام على أفضل خلق الله أجمعين سيدنا محمد وعلى آله وصحبه أجمعين .

\section{وبعسـد}

فهذا بحث يتناول الحديث عن شخصية لها مكانتها في الفكر الإسلامي خاصة فيما يتعلق بعلم الحديث ـ فالحافظ ابن أبي جمرة من أو ائل من تناولو اصحيح الإمام البخاري بالاختصار والشرح ، حتى صار خختصره مقصد الطلاب وغيرهم فشاع وانتشر بين الناس ، واعتمد عليه كثير من جاءوا بعده فشرحوا صحيح البخاري ـ وقد أكثر الإمام الحافظ ابن حجر العسقلاني من النقول عن الحافظ ابن

$$
\text { أبي جمرة في كتابه فتح الباري · ل }
$$

وهذا البحث يتناول بصورة دقيقة جزءا من فكر الإمام الحافظ ابن أبي جمرة

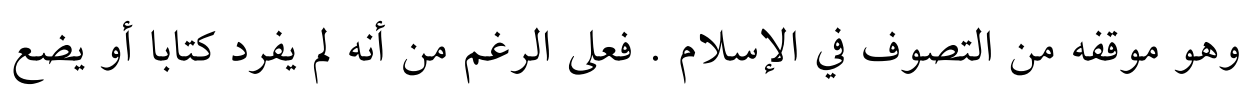

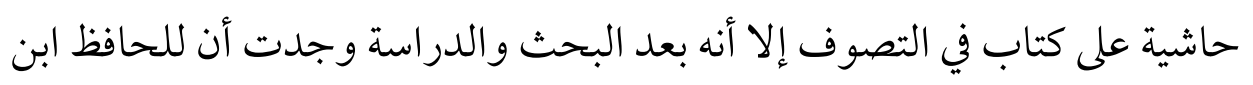
أبي جمرة آراء في التصوف الإسلامي منتشرة في ثنايا كتابه ( بهجة النفوس وتحليها بمعرفة ماها وما عليها ) - وهو الكتاب الذي اختصر به صحيح الإمام البخاري

$$
\text { وقام بشر حه - بجملة أحيانا ومفصلة أحيانا أخرى . }
$$

وترجع أهمية هذا البحث في جمع شتات الكثير من المعلومات المتناثرة والتي

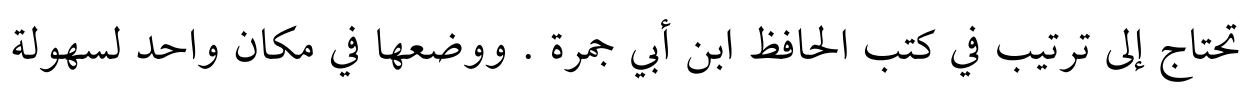




\section{موقف الحافظ ابن أبي جمرة من التصوف}

التعرف على فكر هذا العالم الجليل في مسائل لطالما حدث حول بعضها اختلاف واتهامات لقائليها بمخالفة السنة .

فكان من الواجب بيان رأي العلملء ممن تعلقوا بالسنة وشهد لهم أهل العلم

$$
\text { في زمانهم بالتبحر في العلم والعمل معا على مو افقة الكتاب والسنة . }
$$

فكان هذا البحث الذي أسأل الله تعالى أن يجعله خالصا لو جهه الكريم .

وقد قسمت البحث لعدد من المسائل سوف أتناولها على النحو التالي :

$$
\text { المبحث الأول : التعريف بمفردات البحث . }
$$

المبحث الثاني: موقف الحافظ ابن أبي جمرة من أدعياء التصوف .

المبحث الثالث : موقف الحافظ ابن أبي جمرة من التصوف القائم على الكتاب

والسنة .

أسأل الله تعالى العون و التوفيق والرشاد 
موقف الحافظ ابن أبي جمرة من التصوف

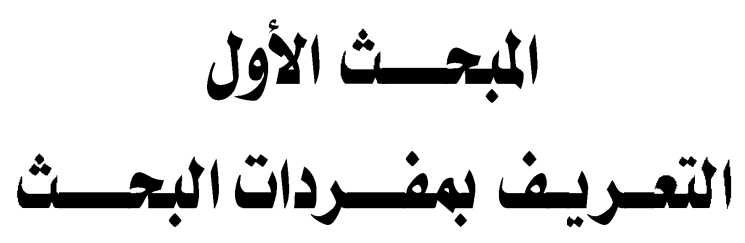




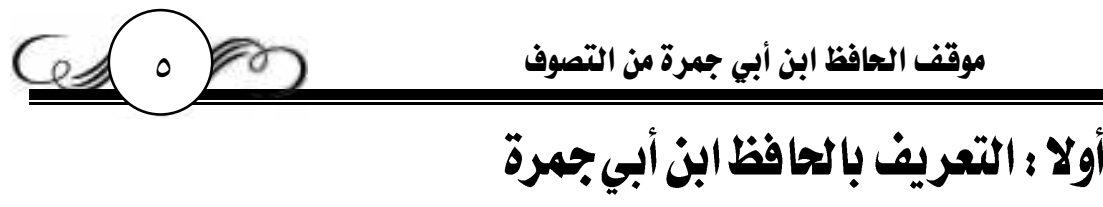

أبو محمد عبداله بن سعد بن سعيد بن أبي جمرة الأزدي الأندلسي (1) أنصاري خزرجي من ذرية سيد الخزرج سعد بن عبادة(()، وهو من بيت كبير بالمغرب ، كان

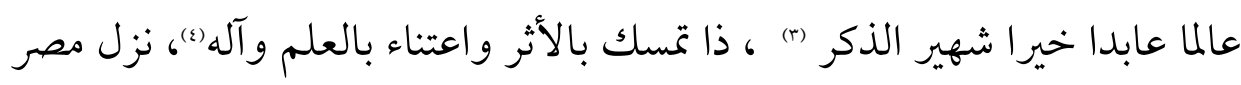
و اشتغل بعلم الحديث وصار من علمائه وكان مالكي المذهب . (o) من كتبه : ( جمع النهاية اختصر به صحيح البخاري ، وكتاب بهجة النفوس وتحليها بمعرفة ماها وما عليها ، وكتاب المرائي الحسان ) (ㄱ.

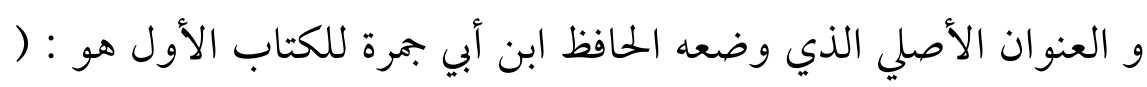
جمع النهاية في بدء الخير والغاية ) ذكر فيه: أنه اتخذ من البخاري ثلاثمائة حديث ويضعاً، بحذف الأسانيد ما عدا راوي الحديث، ليسهل حفظها (v).

$$
\text { الزركلي : الأعلام جـ ع ص } 19 \text { ـ دار العلم للملايين -بيروت-لبنانط } 0 \text { / r . . rم . }
$$
انظر : الشيخ الشنو اني : حاشية على غتصر ابن أبي جمرة ص ص م ـ ـ مصطفى البابي الحلبي - القاهرة plar.

الحافظ ابن حجر : تبصير المتبه بتحرير المشتبه . جـ ا ص OVV ع .تحقيق : كمد علي النجار -علي محمد البجاوي ـ دار الكتب العلمية .بيروت- لبنان .

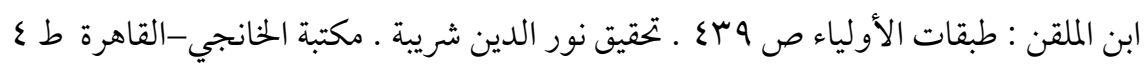
.

$$
\text { المرجع السابق نفسه . } 19 \text { ـ } 19 .
$$

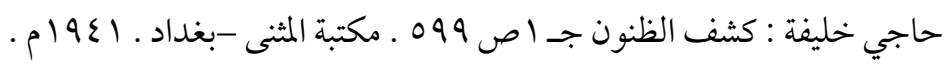




\section{موقف الحافظ ابن أبي جمرة من التصوف 7 CO}

وقد اعتنى بشرح الكتاب الأول عدد من العلم|ء منهم : الشيخ : شهاب

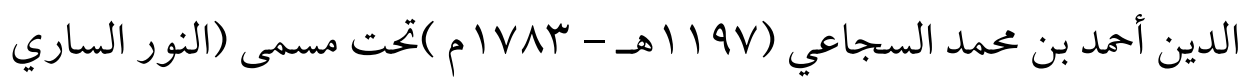
على متن ختصر البخاري لابن أبي جمرة) (1)، و الشيخ محمد الشنواني شيخ الأزهر له حاشية على خختصر ابن أبي جمرة ، طبعت في مطبعة مصطفى البابي الحلبي عام

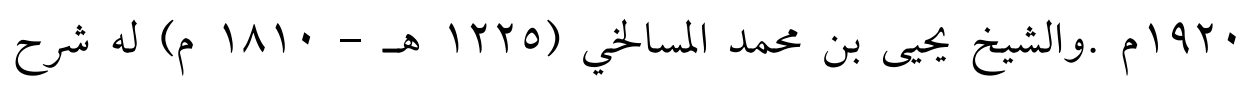
لمختصر أيضا (r)

وقد شرح الحافظ هذا المختصر في كتابه ( بهجة النفوس وتحليها بمعرفة مالها وما عليها ) . طبع في مطبعة الصدق الخيرية مصر في مجلدين وقد حقق الأصل المخطوط ونسخه الشيخ إسماعيل بن عبدالله المغربي الصاوي ، والشيخ الهادي عبدالقادر التونسي، و الشيخ عبدالصمد الحسيني السنان الأزهري ، وفي دار الكتب العلمية بيروت $19 V Y$ و ونشرته دار الجيل ببيروت دون تحقيق . وفي مضمون هذا الكتاب يقول الحافظ : ( هذا الكتاب يحتوي على جمل من درر فرائض الشريعة وسنتها ورغائبها وآدابها وأحكامها والإشارة المى الحقيقة بحقيقتها ، و الإشارة الم كيفية الجممع بين الحقيقة والشريعة وتبين الطرق الناجية التي أشار ( عليه السلام ) إليها ، والإشارة الى بيان أضدادها والتحذير عنها ، عمر كحالة : معجم المؤلفين جـ ا ص ع10 ـالناشر مكتبة المثىى - دار إحياء التراث العربي بيروت .

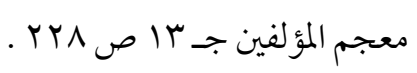




\section{موقف الحافظ ابن أبي جمرة من التصوف}

وربها استدلت على بعض الوجوه التي ظهرت من الحديث بآيات وبأحاديث تناسبها وتقويها فمنها باللفظ ومنها بالمعنى ، وأتبعت ذلك بحكايات ليشحذ الفهم وليتبين بها المعنى وربها أشرت في بعض المواضع الى شيء من توبيخ النفس على غفلتها لعلها تنتهي عن غيها ، وأودعت فيه شيئا من بيان طريق الصحابة وآدابها ، وما يستنبط من حسن عبار اتهم وتحرزهم في نقلهم ، وحسن مخاطبتهم ، وما يستبط من ذلك من آداب الشريعة إذا تعرض لفظ الحديث لشيء من ذلك ) (").وله من

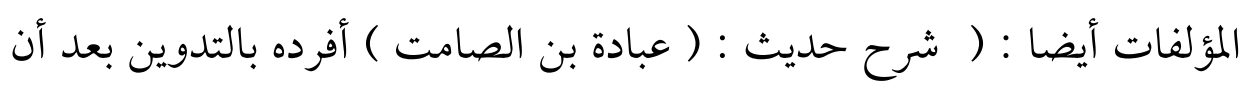
أودعه في كتابه : ( بهجة النفوس ) وهو : قوله - عليه الصلاة والسلام - : ( بايعوني

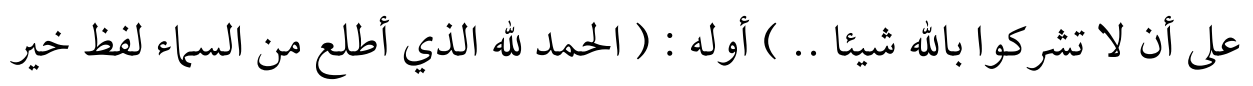

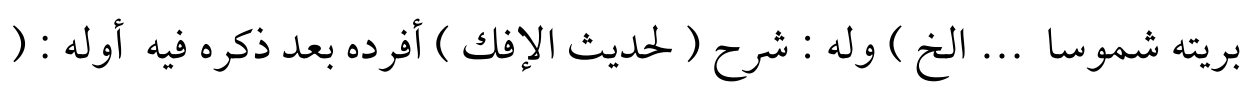

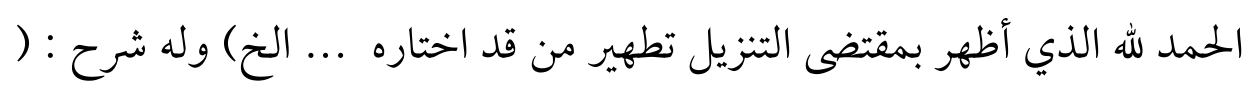

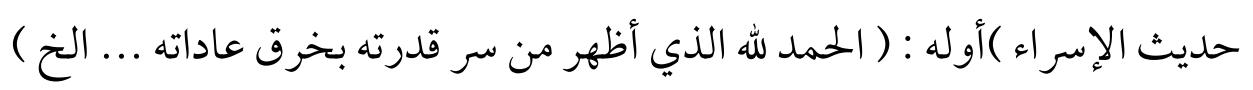
أفرده بالتدوين بعد أن ذكره في كتابه : ( بهجة النفوس ) (r). ومن تلاميذه : محمد بن الحاج صاحب كتاب المدخل (r).

الحافظ ابن أبي جمرة : بهجة النفوس وتحليها بمعرفة مالها وما عليها جـ ا ص ع دار الجيل . بيروت -لبنان .

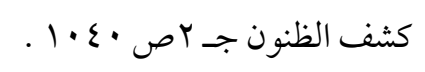

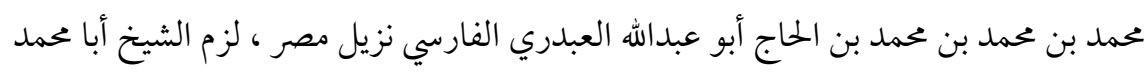

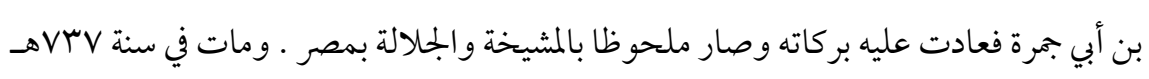
$=$ 


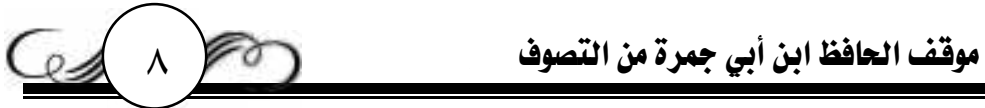

وعن وفاته قال ابن الملقن : ( مات في تاسع عشر من ذي القعدة سنة هV هـ ، وقد شاخ ودفن بالقر افة - بمصر - وقبره معروف يتبرك به ) (1). و قال الزركلي في

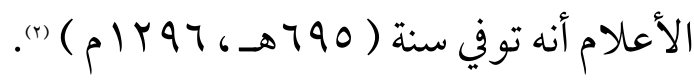

$$
\begin{aligned}
& \text { ثانيًا : الثتقاق لفظظ التصـوف وتعريفـه . }
\end{aligned}
$$

اختلف العلماء في لفظ التصوف من حيث الاشتقاق والجمود ،فالإمام

القشيري يرى أن كلمة " تصوف " غير مشتقة وأن الاشتقاقات لا تشهد لها فيقول :

( ثم هذه التسمية غلبت على هذه الطائفة فيقال : رجل صوفي ، وللجاعة صوفية ،

ومن يتو صل إلى ذلك يقال له : متصوف ، وللجهاعة المتصوفة . وليس يشهد لهذا الاسم من حيث العربية قياس ولا اشتقاق ، والأظهر أنه كاللقب ) (r).

ثم اختلف القائلون بالاشتقاق في مصدره اللغوي والمعنوي ، فأرجعه

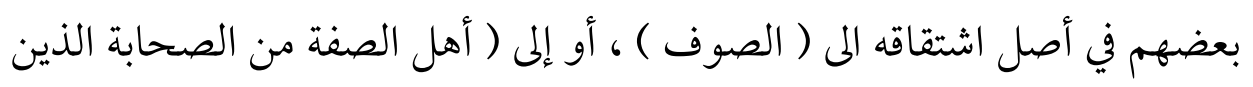

= وقد بلغ الثمانين أو جاوزها ـ انظر : الحافظ ابن حجر : الدرر الكامنة في أعيان المائة الثامنة جـ 0 ص V.0 ـ تحقيق محمد عبدالمعيدضان .الناشر : مجلس دائرة المعارف العثمانية . حيدر أباد

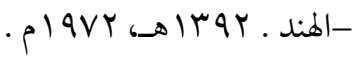

$$
\begin{aligned}
& \text { طبقات الأولياءص qr؟ . }
\end{aligned}
$$

الأعلام جـ ع ص 9 ـ ـ وانظر : الإمام السيوطي : حسن المحاضرة في تاريخ مصر والقاهرة جـ

$$
\text { ا ص rroro . ط ا دار إحياء الكتب العربية . عيسى البابي الحلبي -القاهرة . }
$$

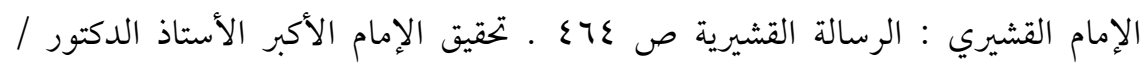

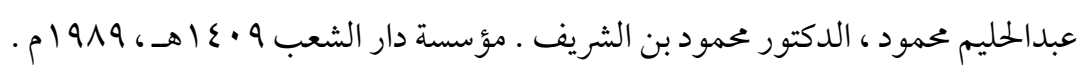




\section{موقف الحافظ ابن أبي جمرة من التصوف}

كانو ا يعيشون في المسجد النبوي لا يفارقوه ) ، أو إلى ( سوفيا التي تعني الحكمة

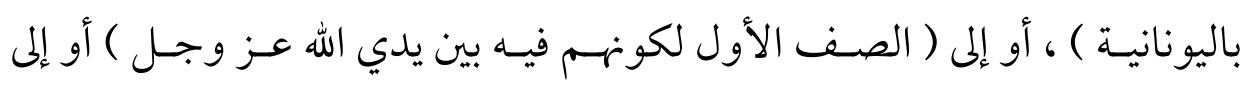

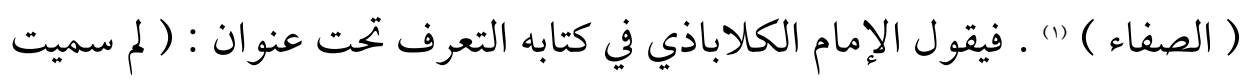

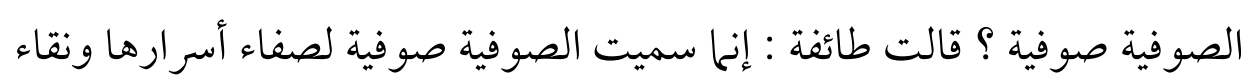

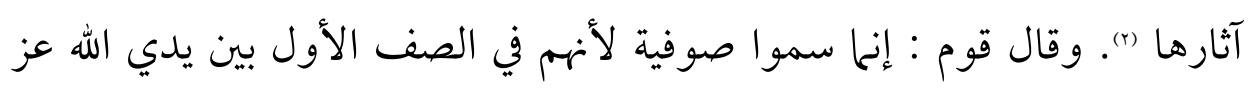

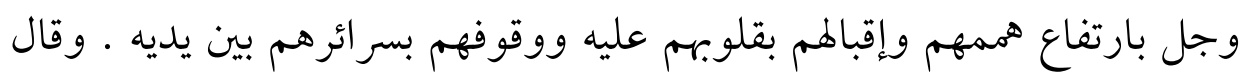

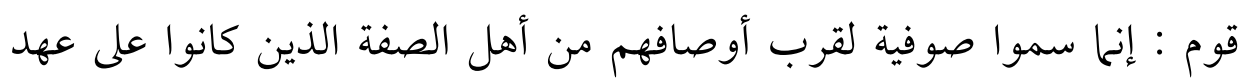
رسول الله الصفة والصوف فقد عبر عن ظاهر أحو الهم ) (r).

وهذا يعني أن التصوف له اشتقاق إجمالا ـ الأول من جهة ظاهم طاهر الحال وفيه

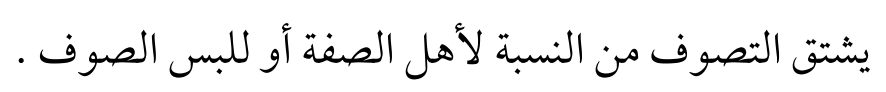

والاشتقاق الثاني من جهة الأحوال وفيه يستمد التصوف اشتقاقه من الصفاء أو من الصف الأول .وقد وجد هذا المعنى عند الإمام بشر بن الحارث الحافي (s) حيث قال : ( الصوفي من صفا قلبه لله ) (Y Y )

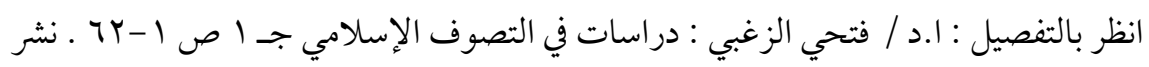

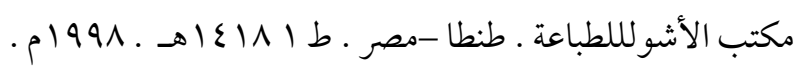
فالتصوف مشتق من الصفاء على هذا المعنى.

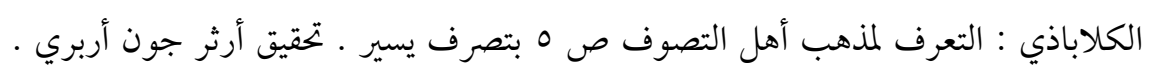

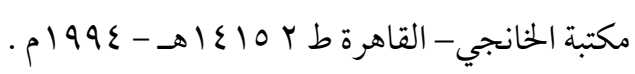

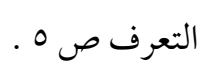




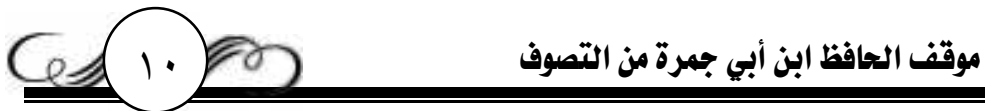

وأما التصوف في الاصطلاح فله تعريفات عدة وصلت إلى أكثر من مائة تعريف ، وذلك يرجع إلى أن كل من تناول التصوف بالتعريف يمكي عن تجربته ونظرته الخاصة به وحده ، فهذا ينظر إلى التصوف على أساس أنه زهد ، والآخر ينظر إليه على أساس أنه خلق ، وغيرهما ينظر إليه على أساس أنه عبادة .

وقد عرفه الإمام الجنيد ( Y ه هـ) : التصوف مبني على ثحان خصال السخاء ، و الرضا ، والصبر ، والإيثار ، والغربة ، ولبس الصوف ، و السياحة ، والفقر · وقال أيضا : التصوف : أن يميتك الحت عنك ، ويمييك به . وقال أبو بكر الكتاني ( r Yrهـ): التصوف صفاء ومشاهدة (1).

ويرى الإمام الأكبر الدكتور / عبدالحليم محمود أن تعريف الإمام الكتاني هو التعريف الراجح للتصوف فيقول : ( إذا نظرنا الى تعريف الكتاني فإننا نجد عبارته المختصرة قد جمعت بين جانين هما اللذان فيما نرى يكونان في وحدة متكاملة تعريف التصوف ـ أحدهما :وسيلة ، و الثاني : غاية أما الوسيلة فهي الصفاء ، وأما الغاية فهي : المشاهدة ـ و التصوف من هذا التعريف طريق وغاية )(r). وهذا التعريف الأخير هو الذي ارتضاه الحافظ ابن أبي جمرة للتصوف ، فهو يرى أن لفظ التصوف مشتق وليس جامدا ، وأن مصدر اشتقاقه الصفاء انظر : الإمام الأكبر الدكتور / عبدالحليم محمود : قضية التصوف :مقدمة كتاب المنقذ من

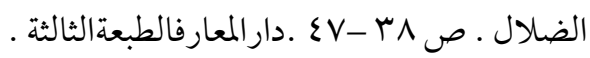

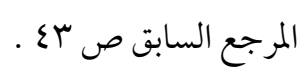




\section{موقف الحافظ ابن أبي جمرة من التصوف 111 CO}

فيقول:(فلم) صفت بو اطنهم تسمو اباسم الصوفة وهو مشتق من الصفاء) (1).

\section{الأسماء اللدالة على الصوفية عند الجافظ ابن أبي جمرة}

رغم أن الحافظ ابن أبي جمرة يرى اشتقاق التصوف من الصفاء إلا أنه قد

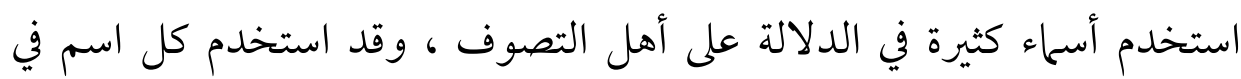

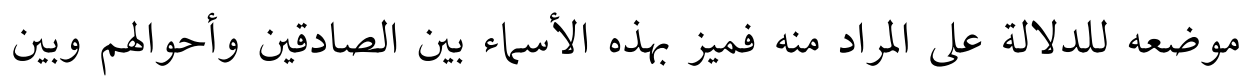

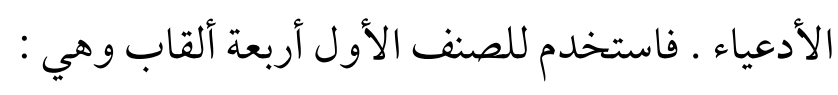

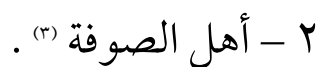

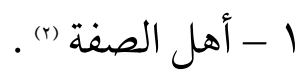

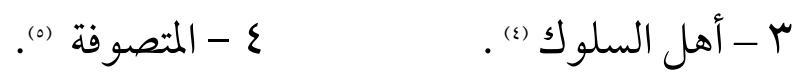

واستخدم للأدعياء لقب " المتصو فة والمنتسبون للمتصوفة "

$$
\begin{aligned}
& \text { بهجة النفوس جـ ا ص Y I . وانظرجـ ا ص حسا . } \\
& \text { نفسه جـ ا ص ع r . }
\end{aligned}
$$

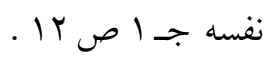

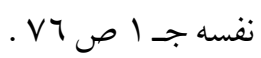

$$
\begin{aligned}
& \text { نفسه جـ اص ص } 19 .
\end{aligned}
$$


موقف الحافظ ابن أبي جمرة من التصوف

\section{المبحسث الثانـي \\ موقف الحافظ ابن أبي بمرة من أدعياء التصوف}




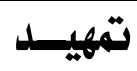

فرق الحافظ ابن أبي جمرة بين نوعين من الصوفية في نستهم للصدق في التصوف من عدمه ، فنسب الصادقين للصفاء وسماهم بأهل الصفة والصوفية

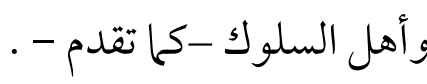

أما النوع الآخر فيراه الحافظ ابن أبي جمرة منتسبا للتصوف وليس من أهله فهم أهل دعاوى غير حقيقية . وقد عاب الحافظ في كلامه على المنتسبين للتصوف عددا من المسائل ثم بين

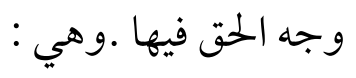

\section{1 - العبادة لأجل ظهورالكرامة.}

تمثل العبادة في الإسلام الغاية التي خلق الإنسان لها ، بل وكل المخلوقات

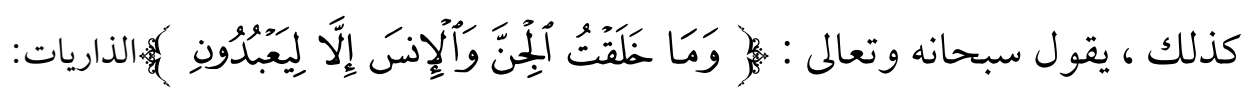
1ه) والله تعلى أحق بأن يعبد لأنه وحده رب السماوات والأرض ، فلا إله إلا هو

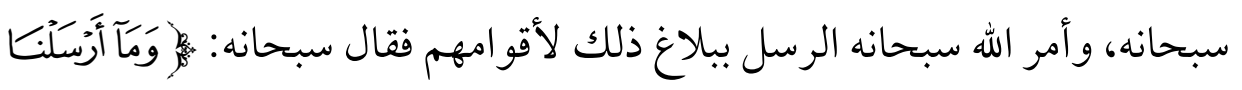

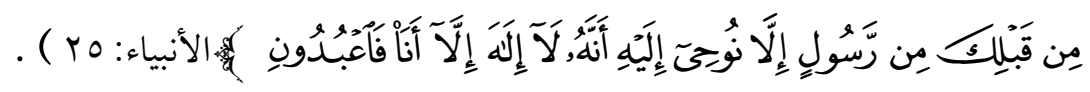

وقد اهتم الصوفية بالعبادة اهتماما كبيرا على اعتبار أنها الطريق الوحيد الموصل لله سبحانه وتعالى ، مؤكدين على أنه لابد أن تخلو العبادة لله تعالى من كل بل بلى حظ ، وأن يجفظ العابد فيها نفسه من كل شَرَك قد يعيقه عن الوصول لله سبحانه وتعالى وعن الإخلاص التام . 


\section{Ces 18}

\section{موقف الحافظ ابن أبي جمرة من التصوف}

و من هذه الأمور انتظار الأجر بعد العمل ، والجزاء بعد العبادة مباشرة بأن يرى العبد ذلك لنفسه عاجلا ، وهذا خطأ يخرج عن الإخلاص في العبادة ، بل جعله السراج الطوسي شخرجا عن بجمل تحقيق العبودية التام لله سبحانه وتعالى فيقول في كتابه اللمع: (تكلم قوم من المتقدمين في معنى الحرية والعبودية على معنى: أن العبد لا ينبغي أن يكون في الأحوال ، والمقامات التي بينه وبين الله تعالى كالأحرار ، لأن من عادة الأحرار طلب الأجرة ، وانتظار العوض على ما يعملون من الأعهال ، وليست عادة العبيد كذلك ؛ لأن العبد لا ينتظر من مولاه أجرة ولا عوضا على ما يأمره به مولاه ، فمتى طمع في شيء من ذلك فقد ترك سمة العبيد ؛ لأن العبيد إن أعطاهم مو لاهم عطية على ما أمرهم به ، واستعملهم فيه كان ذلك (1) من تفضل مولاهم عليهم لا باستحقاقهم) ولقد وصف الحافظ ابن أبي جمرة أصحاب هذه الأفعال بالجهل مفرقا بين السالكين الفضلاء وبين هؤلاء ، فيقول عند شرحه لحديث ( من قاتل لتكون كلمة الله هي العليا فهو في سبيل الله) (r) : ( هنا إشارة صوفية لأن الجهاد عندهم هو انظر : السراج الطوسي : اللمع ص اسه ـ تحقيق : الإمام الأكبر الأستاذ الدكتور / عبدالحليم

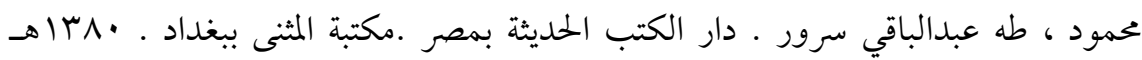
$\cdot 197$. أخرجه الإمام البخاري ـ كتاب الجهاد ـ باب من قاتل لتكون كلمة الله هي العليا جـ ب ص

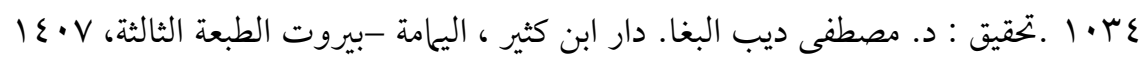




\section{موقف الحافظ ابن أبي جمرة من التصوف 10 C}

الجهاد الأكبر ، كما أخبر|لمالفي غير هذا الحديث حين رجع من الجهاد فقال للصحابة : " هبطتم من الجهاد الأصغر إلى الجهاد الأكبر " (1) ، والجهاد الأكبر هو جهاد النفس ، فتكون مجاهدتهم لها لأن تكون كلمة الله هي العليا ، كما أخبر عز وجل على لسان نبيه||له: (لا يزال العبد يتقرب المي بالنوافل حتى أحبه فإذا أحببته كنت سمعه الذي يسمع به وبصره الذي يبصر به ويده التي يبطش بها ) (r) هذا هو طريق السادة الفضلاء منهم • وأما الذي يقول أهل الجهل : نواصل ونجاهد حتى نرى شيئا من خرق العادات والكر امات فأولئك عندهم جهال ، ومنهم من قال : إنهم يدخلون

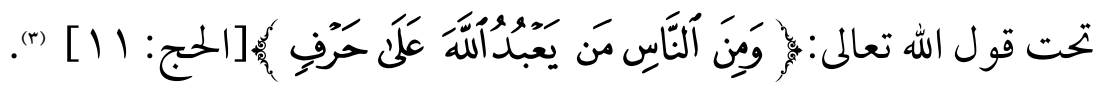
وفي نفس المعنى ينقل الشيخ عبدالقادر الجيلاني قول بعضهم : ( عباد الله عز وجل الذين تحققت عبوديتهم له لا يطلبون منه دنيا ولا آخرة ، وإنها يطلبون منه هو لا غيره (

أخرجه البيهقي في كتاب الزهد الكبير عن جابرلملهلفظ قريب من لفظ الحديث ـ وقال : هذا إسناد فيه ضعف ـ الزهد الكبير للبيهقي ص 170 ـ ـتحقيق الشيخ عامر أحمد حيدر ـ مؤسسة

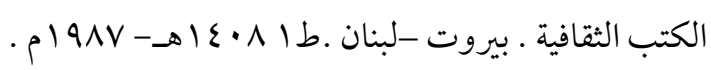

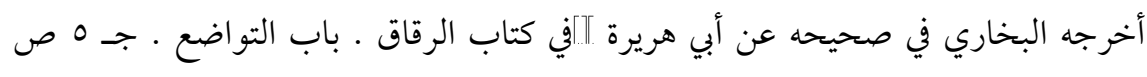
rrAE

$$
\text { انظر : بهجة النفوس جـ الص } 101 \text {. }
$$

انظر : الشيخ عبدالقادر الجيلاني : الفتح الرباني ص •V-V • قدم له : خليل الميسي . دار

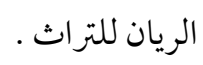




\section{r - ترك العله الشرعي وادعائ العلم اللداني.}

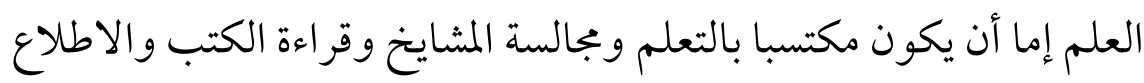

،أو يكون علم) لدنيا ، وهو ذلك العلم الذي يهبه الله لمن يشاء من عباده دون

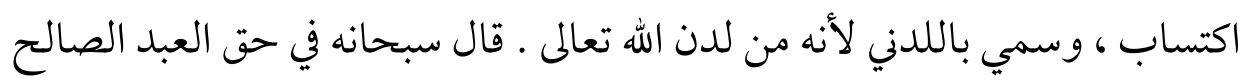
: ووضعوا له الفوارق الشارحة لكل قسم ـيقول الشيخ زروق ( 99 هــ ) : ( العلم

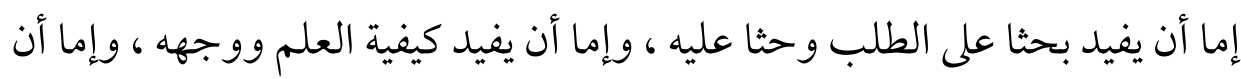

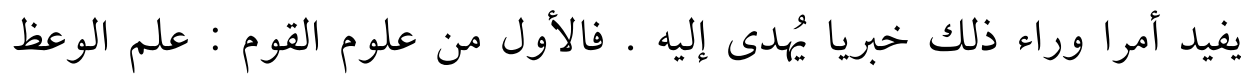

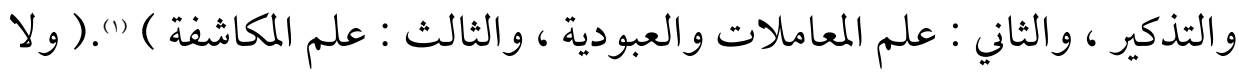
علم إلا بتعليم من الشارع أو من ناب منابه إنابة ، وما تفيده العبادة والتقوى ، إنما هو فهم يو افق الأصول ويشرح الصدور ، ويوسع العقول ) (ل). و العلوم جميعها عند الصوفية لابد وأن توصل الى الله تعالى ومعرفته حق حقون معرفته ، يقول الشيخ ابن عجيبة ( TYO (هـ) : ( العلوم ثلاثة : علم يتعلق بإظهار الظاهر ويسمى : علم الشريعة وعلم الحكمة ، وعلم يتعلق بإصلاح الباطن ، ويسمى علم التصوف وعلم الطريق ، وهما كسبيان ، وعلم موهوب ، ويسمى علم الحقيقة ، وهو الثمرة والغاية ، فكل علم لا يو صل صاحبه لعلم الحقيقة فهو ناقص

الشيخ زروق الفاسي : قواعد التصوف ص • ، . تحقيق : عبدالمجيد خيالي ـ دار الكتب العلمية

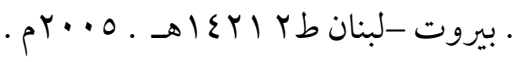

$$
\begin{aligned}
& \text { قواعد التصوف ص آب بتصرف. }
\end{aligned}
$$




\section{ClV موقف الحافظ ابن أبي جمرة من التصوف}

، إذ ثمرة العلم العمل ، وثمرة العمل الحال ، وثمرة الحال الذوق و الوجدان ، وهو نهاية العرفان ، ولابد من شيخ مرب ينقل المريد من علم الشريعة إلى علم الطريقة

$$
\text { مع تحقيت الشريعة )(') }
$$

فادعاء العلم اللدني لابد أن يكون بعد التحقق بالعلم الشرعي ، فالترتيب الذي ذكره الشيخ ابن عجيبة مقصود ، وهو ما نادى به المحققون من أهل التصوف جميعا .

أما ادعاء عكس ذلك فهو جهل واضح على حد تعبير الحافظ ابن أبي جمرة الذي يقول :( ثم بقي بحث مع بعض المنتسبين للمتصوفة حيث يأتون بألفاظ يدعونها فمنها قولم بالعلم اللدني ويؤثرونه على علم الشرع المنقول ، ويقولون : إنهم أخذو بغير واسطة وغيرهم أخذ بالو اسطة ، وهذا منهم جهل وخطأ لا شك فيه و لا خفاء )

ثم يوضح الحافظ ابن أبي همرة ما يجب تحققه في العلم اللدني حتى يصح التفريق فيه بين الصادق والدعي ، فهناك شروط لابد من توافرها فيمن يدعي أن عنده علم) لدنيا يعلم به ، فيقول : ( والحق في هذا الموضع أن يقال : العلم اللدني هو حق لاشك فيه ، لكن الدليل على تصديق من ادعى وجوده أن يكون علمه على الكتاب والسنة خالصا من الشوائب صادقا في توجهه عارفا بالخواطر صالحها

انظر : الشيخ أحمد بن عجيبة : شرح صلاة القطب ابن مشيش ص اب. تحقيق : العمراني

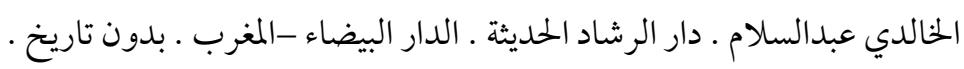

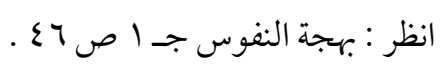




\section{موقف الحافظ ابن أبي جمرة من التصوف 1110010}

وفاسدها معرفة كلية ؛ لأن علم الخواطر قائم بذاته )(1).

وهذا الذي ذكره الحافظ هو ما أكده كبار مشايخ الصوفية المحققين، يقول الإمام الجنيد : ( من لم يسمع الحديث ، ويجالس الفقهاء ، ويأخذ أدبه عن المتأدبين

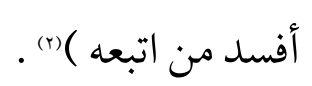

و الحق أن كبار المشايخ كانوا يتعلمون العلم الشرعي مع كونهم قد رُزقوا العلم اللدني فجمعوا بين العلمين معا مع شدة العلم الشرعي عليهم · فيروي الهجويري عن أبي يزيد البسطامي قوله : ( عملت في المجاهدة ثلاثين سنة فم) وجدت شيئا أشد علي من العلم ومتابعته ) . ثم يعلق الهجويري قائلا : ( والحقيقة أن الطبع أميل إلى الجهال منه إلى العلم ، ويمكن عمل الكثير بالجهل دون مشقة ، و لا يمكن الخطوة واحدة بالعلم دون عناء ، وصر اط الشريعة أدق وأخطر كثيرا من صر اط الآخرة -لأنه دال عليه فمن استقام هنا استقام هناك -و كل دعاوى المدعين تتلاشى في ممارسة الشريعة، ويتعرى أمامها كل أرباب اللسان ) (r). وبالرغم من هذه الدقة في قبول العلم اللدني ، ووضع شروط لقبوله كما ذكرها الحافظ ابن أبي جمرة وغيره من مشايخ الصوفية ، والتحذير من القول به إلا

$$
\begin{aligned}
& \text { انظر : بهجة النفوس جـ ا ص VV . . }
\end{aligned}
$$

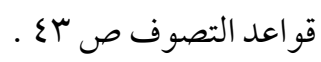

انظر : الهجويري : كشف المحجوب ص ماب ـ ـ دراسةوترجمةوتعليقالدكتورة / إسعاد قنديل .

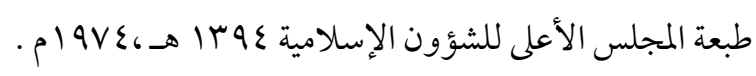




\section{Cيك الحافظ ابن أبي جمرة من التصوف 19}

على موافقة الكتاب و السنة ، فإن الصوفية أكدوا على أن العلم اللدني أو الإلهام أو الكشف لا يتعدى صاحبه من حيث العمل ، فهو حال فردي ، يقول الشيخ زروق : ( مبنى العلم على البحث والتحقيق ، ومبنى الحال على التسليم والتصديق ، فإذا تكلم العارف من حيث العلم نظر في قوله بأصله من الكتاب و السنة وآثار السلف ، لأن العلم معتبر بأصله ، وإذا تكلم من حيث الحال ، سلم له ذوقه ، إذ لايوصل إليه إلا بمثله ، فهو معتبر بو جدانه ـ فالعلم به مستند لأمانة صاحبه ، ثم لا يقتدى به

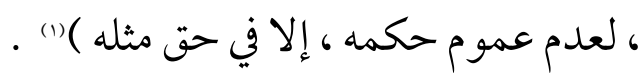

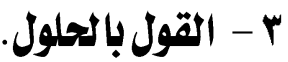

الحلول : ( كون الشيء حاصلا في الشيء ومختصا به بحيث تكون الإشارة إلى

أحدهما إشارة إلى الآخر تحقيقا أو تقديرا ، والحلول نوعان : حلول جواري ، وحلول سرياني ، فالجواري : عبارة عن كون أحد الجمسمين ظرفا للآخر كحلول الماء في الكوز • و الحلول السرياني عبارة عن اتحاد الجمسين بحيث تكون الإشارة إلى أحدهما إشارة إلى الآخر كحلول ماء الورد في الورد ، فيسمى الساري فيه حالا (r) والمسري فيه محلا ) وقد أجمع الصوفية على رفض نظرية الحلول ، مؤكدين على أن الله تعالى منزه

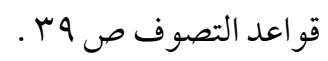

انظر : أبو البقـاء الفكومي : الكليـات ص م •7 ـ تحقيق عـدنان درويش - محمد = المصري .

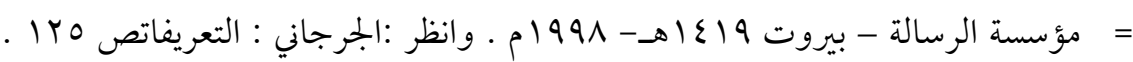
تقفيق :إبراهيم الإبياري ـ دارالكتابالعربي .بيروت-لبنان 0 اع اهـ 
عن الحلول والاتحاد بالأجسام مستدلين على ذلك بالقر آن وأدلة العقل .

فبداية أجمعو اعلى أنه سبحانه وتعالى ( ليس بجسم ولا شبح ولا صورة ولا لا لهال

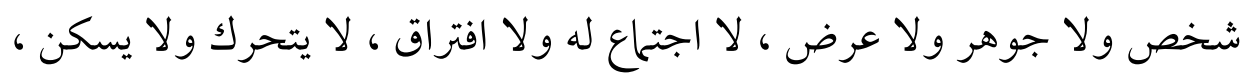

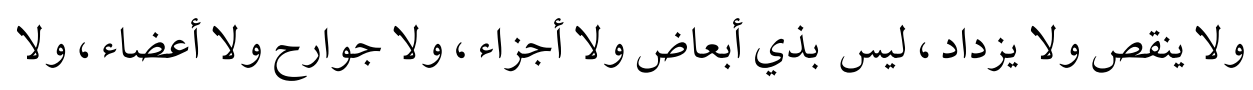

بذي جهات ولا أماكن ، لا تجري عليه الآفات ، ولا تأخذه السنات ولا تداوله الأوقات ، ولا تعينه الإشارات ، لا يجويه مكان و لا يجري عليه زمان ، لا تجوز عليه

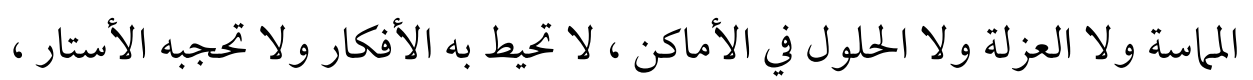

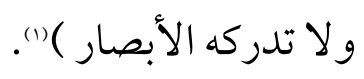

ويقول الطوسي في اللمع : ( والله تعالى موصوف بها وصف به نفسه ، كما

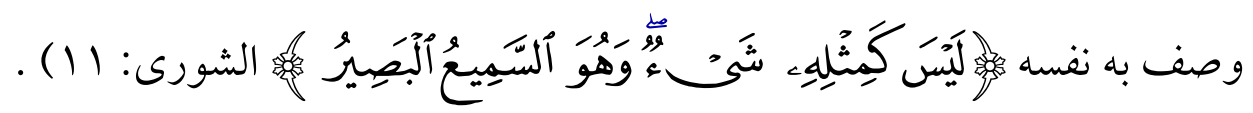

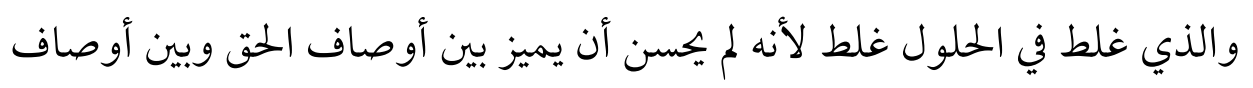

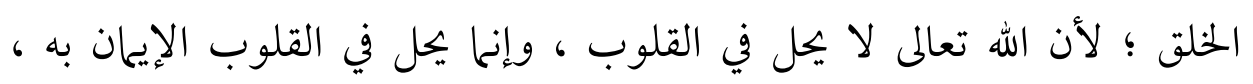

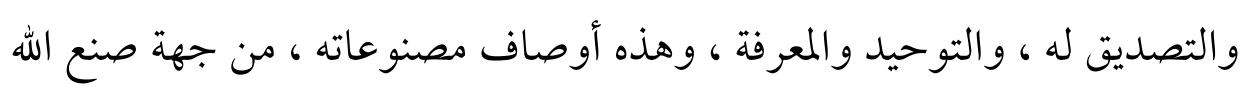

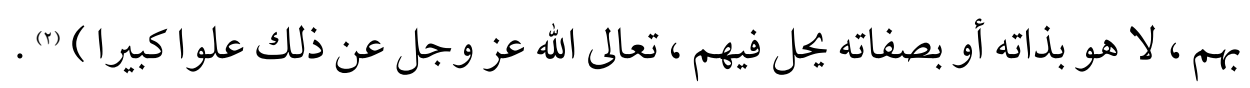
وينقل الإمام القشيري عن الإمام الجنيد قوله في نفي الحلول مع التعجب من قائل هذا القول : ( متى يتصل من لا شبيه له ولا نظير بمن له شبيه ونظير ؟!

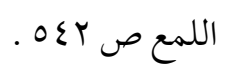




\section{موقف الحافظ ابن أبي جمرة من التصوف}

هيهات هذا ظن عجيب إلا بما لطف اللطيف من حيث لا درك ، ولا وهم ولا إحاطة إلا إشارة اليقين وتحقيق الإيمان )(').

وتبرأ الصوفية من هذه المقالة ومن قائليها ، فالطوسي في اللمع يعدد أصناف

الحلوليين ويؤكد ضلالهم وبعدهم عن الملة قائلا : ( بلغني أن جماعة من الحلولية ، زعموا أن الحق تعالى ذكره ، اصطفى أجساما حل فيها ، بمعاني الربوبية ، وأزال عنها معاني البشرية .... فبلغني أن منهم من قال بالأنوار ، ومنهم من قال بالنظر الى الشواهد المستحسنات نظرا يجهل ، ومنهم من قال : حال في المستحسنات وغير المستحسنات ، ومنهم من قال : حال في المستحسنات فقط ، ومنهم من قال : على

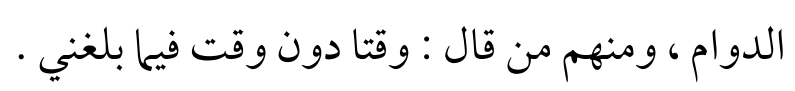

فمن صح عنه شيء من هذه المقالات : فهو ضال بإجماع الأمة ، كافر ، يلزمه

$$
\text { الكفر فيها أشار إليه )(r) }
$$

فالطوسي وغيره يكفرون المقالة ولم يثبت عندهم أن أحدا من الصوفية قال هها ، فيقول الطوسي : ( باب ذكر غلط الحلولية ، وأقاويلهم على ما بلغني ، فلم

$$
\text { أعرف منهم أحدا ، ولم يصح عندي شيء غير البلاغ ) (م). }
$$

وقد صنف الحافظ ابن أبي جمرة القول بالحلول تحت الأقو ال الشنيعة فيقول :

( ومنهم قوم يأتون بلفظ شنيع فيقولون : أنا هو وهو أنا . ويدعون ذلك حالا

$$
\begin{aligned}
& \text { الرسالة القشيرية ص بr } \\
& \text { اللمع ص إعه .بتصرف }
\end{aligned}
$$

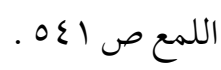




\section{موقف الحافظ ابن أبي جمرة من التصوف}

$$
\text { ويجعلونه من الأحوال الرفيعة العظيمة . }
$$

وقائل هذا إما أن يكون قد غطي على عقله فقال هذا وهو لا يعقل ما قال ، فقد ارتفع الخطاب عن هذا فلا يلتفت إلى كلامه ولا توبة له ولا يحسب مقاما بل هو ضرب من الجنون (1) وإما أن يكون جاهلا يحكي عن غيره، وليس له بذلك حال فهذا ينبغي تأديبه لأن ذلك مستحيل عقلا وشرعا ، وهو أن يرجع الخالق مخلوقا والمخلوق خالقا . وإما أن يكون له مذهب فاسد ، فلما أن تعلق بطريق صرح به وجعله حالا ) (r). وقد نقل مثل هذا القول عن الإمام ابن تيمية( VYAهـ ) حيث قال في الرسائل والمسائل : (بعض ذوي الأحو ال قد يحصل له في حال الفناء القاصر سكر وغيبة عن السوى ، والسكر وجد بلا تمييز فقد يقول في تلك الحال سبحاني، أو ما في الجبة إلا الله، أو نحو ذلك من الكلمات التي تؤثر عن أبي يزيد البسطامي أو غيره من الأصحاء، وكلمات السكر أن تطوى ولا تروى ولا تؤدى إذا لم يكن سكره بسبب محظور من عبادة أو وجه منهي عنه. فأما إذا كان السبب عظوراً لم يكن السكران معذوراً، لا فرق في ذاك بين

نلاحظ أن الحافظ ابن أبي جمرة يلتمس العذر لصاحب القول من باب إحسان الظن ، خاصة فيما

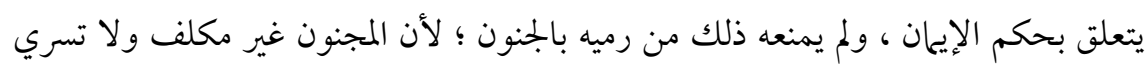
عليه الأحكام الشرعية ولا يعد قوله حالا أو مقاما أو منسوبا لطائفة معينة ، فكلام المجنون عليه وحده.

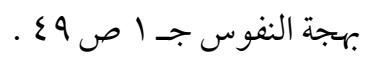




\section{موقف الحافظ ابن أبي جمرة من التصوف}

السكر الجسماني والروحاني فسكر الأجسام بالطعام والشراب، وسكر النفوس بالصور، وسكر الأرواح بالأصوات، وفي مثل هذا الحال غلط من غلط بدعوى الاتحاد والحلول العيني في مثل دعوى النصارى في المسيح، ودعوى الغالية في علي وأهل البيت، ودعوى قوم من الجهال الغالية في مثل الحلاج أو الحاكم بمصر أو غيرهما، وربيا اشتبه عليهم الاتحاد النوعي الحكمي بالاتحاد العيني الذاتي )('). ومما سبق يتضح أن الحافظ ابن أبي جمرة يوافق المحققين من الصوفية حيث

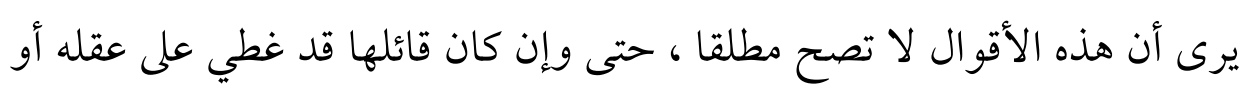
ينقلها جهلا ، ويرى أن حال أهل الثبات أولى بالقبول ، وهو الحال الأكمل فيقول :

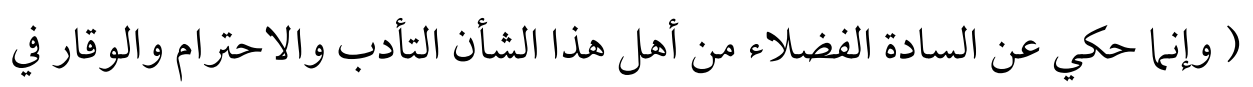
مقاماتهم ، ولم يخل قط بأدب من آداب الشريعة لا في حال حضورهم ولا في حال

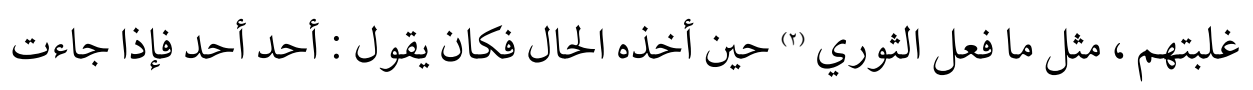
الصلاة صلى (r)

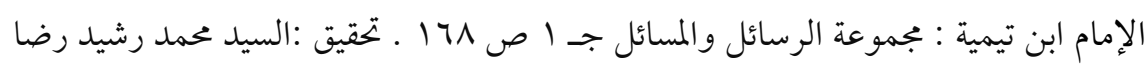

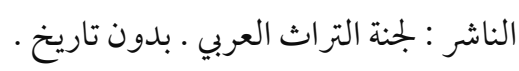

سفيان بن سعيد بن مسروق الثوري أبو عبد الله الكوفي ثقة حافظ فقيه عابد إمام حجة من رؤوس الطبقة السابعة وكان ربها دلس مات سنة مائة وإحدى وستين وله أربع وستون سنة .

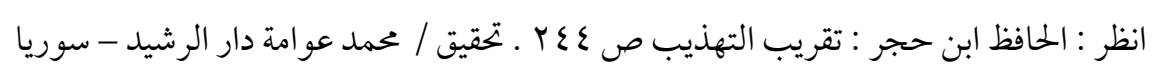

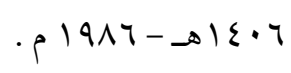

$$
\begin{aligned}
& \text { بهجة النفوس جـ ا ص 9 \ بتصرف }
\end{aligned}
$$




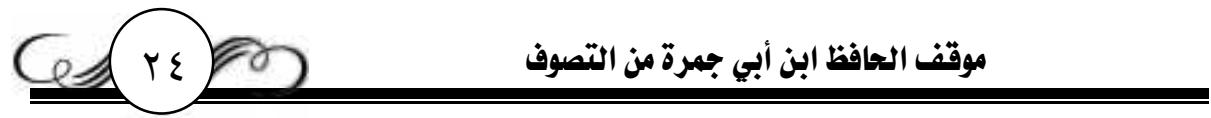

\section{المبحسـث الثالــث}

\section{موقف الجافظظابن أبي جمـرة من التصـوف السني}




\section{ملحح طريقهم لالتزامهم بالشرعدون الأدعياء}

ظهر أن الحافظ ابن أبي جمرة قد قسم الصوفية إلى قسمين : فضلاء وأدعياء أو منتسبين على حسب تعبيره ، وقد عاب على المنتسبين والأدعياء عدم تمسكهم بالكتاب و السنة ، وقول بعضهم بالحلول .

أما القسم الأول فإن الحافظ يرى حسن طريقتهم وحسن بجاهدتهم ، وجميل سيرهم إلى الله تعالى خاصة وأن سيرهم إلى الله تعالى على الكتاب و السنة . فإن الصوفية قد تمسكوا بالكتاب والسنة في طريق سيرهم إلى الله تعالى ولم يقتنعوا بأذواق ومو اجيد وأحوال إلا إذا كانت على الكتاب و السنة فعلى سبيل المثال

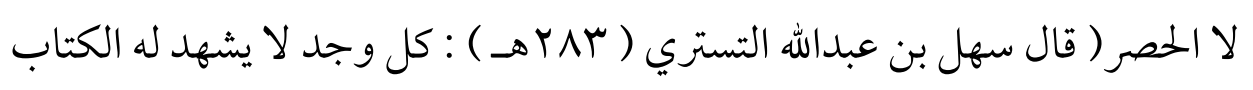
والسنة فباطل ، وقال أبو سليان الداراني ( 10 بهـ) : ربها تنكت الحقيقة قلبي أربعين يوما فلا آذن لها أن تدخل قلبي إلا بشاهدين من الكتاب و والسنة )(1).

وقد شهد لهم الإمام الشاطبي( •Vوهـ) في كتابه الاعتصام بذلك قائلا : (الوجه الرابع من النقل : ما جاء في ذم البدع وأهلها عن الصوفية المشهورين عند الناس ، وإنما خصصنا هذا الموضع بالذكر وإن كان فيما تقدم من النقل كفاية() ؛ لأن

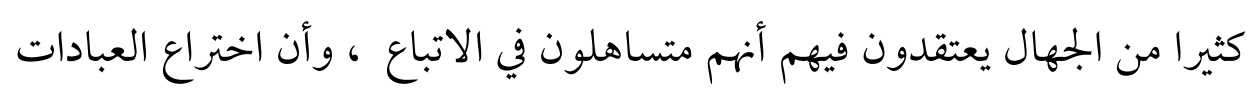
و التزام ما لم يأت في الشرع التزامه مما يقولون به ، ويعملون عليه ــ وحاشاهم من من بهن

$$
\text { يقصد النقل عن الكتاب والسنة وأقوال السلف . }
$$




\section{موقف الحافظ ابن أبي جمرة من التصوف}

ذلك أن يعتقدوه أو يقولوا به فأول شيء بنو اعليه طريقتهم اتباع السنة واجتناب ما

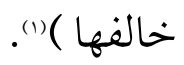

فيمدح الحافظ طريقتهم في جاهدة النفس متخذا منها سبيلا لحسن طريقة أهل التصوف إجمالا مبينا أن هذا المدح قد استحقوه لالتزامهم بالشرع أشد التزام.

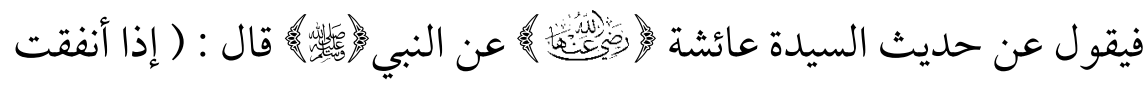
المرأة من طعام بيتها غير مفسدة كان لها أجرها بها أنفقت ولزوجها أجره بها كسب وللخازن مثل ذلك لا ينقص بعضهم أجر بعض شيئا ) (r). أن فيه ( دليل لحسن طريق أهل الصوفة فإن كل ما كان فيه خخالفة للنفس ولم يكن ممنوع شرعا فإن صاحبه في ذلك مأجور • إذا استقريت (r) هذه القاعدة بحسب قواعد الشريعة تجدها إن شاء الله غير منكسرة فأخذ أهل الطريق من أجل ذلك في خخالفتها مرة

$$
\text { واحدة ) }
$$

وأما تفصيلا فقد استدل الحافظ ابن أبي جمرة على حسن طريق أهل التصوف

بأدلة من السنة ذكرها للدلالة على التزام الصوفية في أفعالهم بالكتاب والسنة ،

انظر : الإمام الشاطبي : الاعتصام جـ ا ص 19 ا ـ تحقيق: سليم بن عيد الهلالي .دار ابن عفان،

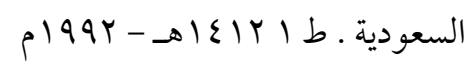

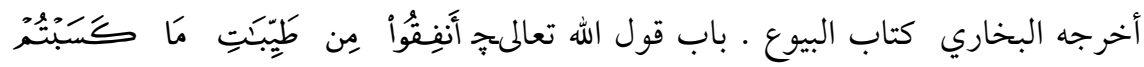

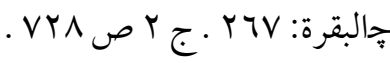

$$
\begin{aligned}
& \text { يعني : استقرأت بإبدال الهمزة . }
\end{aligned}
$$

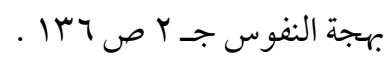




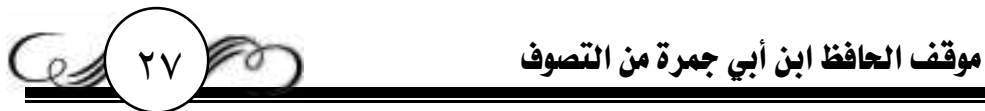

وجعلها قيدا يستحق فاعله المدح وتاركه اللوم ، وقاعدة للتفريق بين الصادق

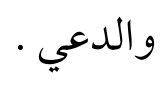

\section{أولا : ذكر الله تعالى}

ذكر الله تعالى من أفضل الأعحال التي يتقرب بها العبد لله تعالى ، وهو من الأعحال التي لم يحدها الشرع بعدد او بوقت بل ورد الأمر الإلهي فيه بالكثرة ، فقال

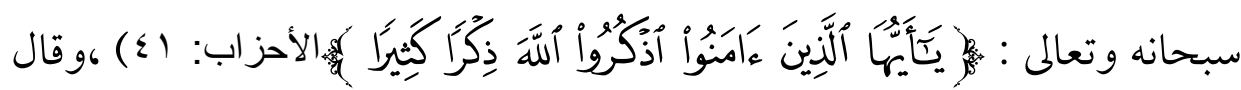

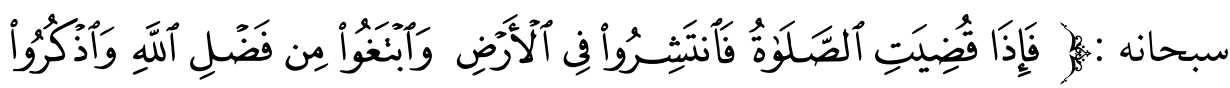

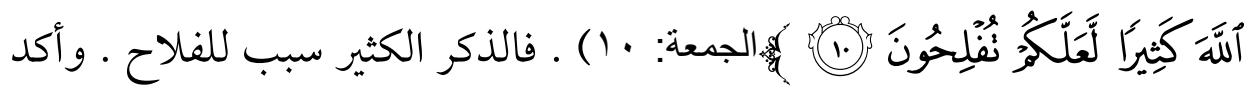
تلك المعاني القرآية النبي

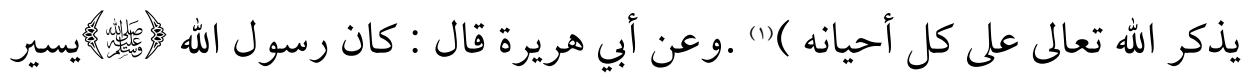
في طريق مكة فمر على جبل يقال له : جمدان فقال : ( سيروا هذا جمدان سبق المفردون سبق المفردون ) قالو ا : يا رسول الهه ما المفردون ؟ قال : ( الذاكرون الله

$$
\text { كثير او الذاكرات ) (r) (r) }
$$

وقد اهتم الصوفية في أورادهم بإعلاء أمر ذكر الله تعالى ، حتى جعلوه هو

الأساس في الطريق الى الله تعالى ، يقول الإمام القشيري : ( الذكر ركن قوي في طريق الحق سبحانه وتعالى ، بل هو العمدة في هذا الطريق ، ولا يصل أحد إلى الله

$$
\text { أخرجه الإمام مسلم في صحيحه ـ باب ذكر الله تعالى في حال الجنابة ـ جـ ال ص ع 19 ـ . }
$$




\section{موقف الحافظ ابن أبي جمرة من التصوف}

إلا بدوام الذكر • وقال الثوري : لكل شيء عقوبة وعقوبة العارف انقطاعه عن ذكر الله تعالى )('). ويقول الشيخ ابن عجية : ( الذكر إذا أطلق ينصرف لذكر اللسان ، وهو ركن قوي في الوصول ، وهو منشور الولاية ، فمن ألهم الذكر فقد أعطي المنشور ، ومن سلب الذكر فقد عزل ) (r).

والحافظ ابن أبي جمرة يرى أن الصوفية فضلو ابهذا الأمر فيقول : في حديث : ( من قال لا إله إلا الله وحده لا شريك له له الملك وله الحمد وهو على شيء قدير . في يوم مائة مرة كانت له عدل عشر رقاب وكتبت له مائة حسنة ومحيت عنه مائة سيئة وكانت له حرزا من الشيطان يومه ذلك حتى يمسي ولم يأت أحد بأفضل مما جاء به إلا أحد عمل أكثر من ذلك )(r) دليل على تفضيل أهل الصوفة ، يؤخذ ذلك من جعل هذا الأجر العظيم لمن قال هذا القول مائة مرة ، فكيف بمن هو يومه كله هكذا لا يفتر إلا عند أداء فريضة أو ضرورة البشرية فإن طريقهم مبني على دوام

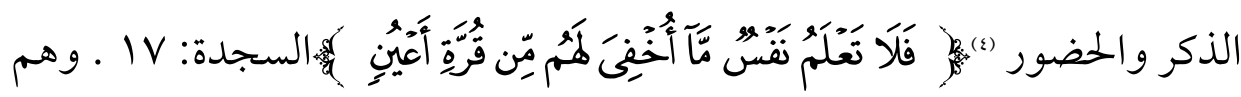
في ذلك متبعون لسنة سيدنا رسول الله

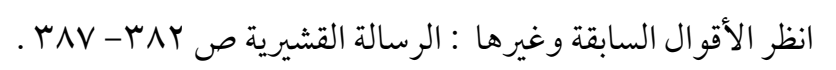

الشيخ أحمد بن عجيبة : معراج التشوف إلى حقائق التصوف ص صل Vع ـ تحقيق د / عبدالمجيد

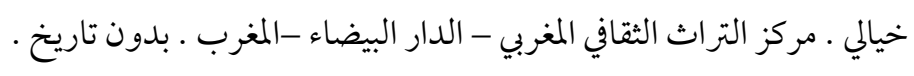

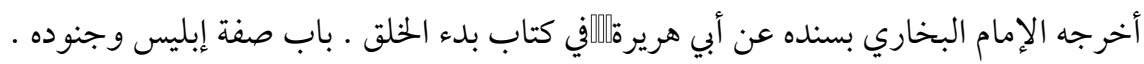

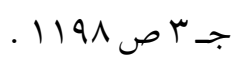

$$
\text { انظر الأقوال السابقة وغيرها : الرسالة القشيرية ص rی }
$$




\section{موقف الحافظ ابن أبي جمرة من التصوف}

كان طويل الصمت كثير الذكر وعلى هذا بنو اطريقهم ، وقد قال آدمي من عمل أنجى له من عذاب الله من ذكر الله" (1))(r).

فذكر الله إذا هو الوسيلة للوصول إلى غاية عظمى ، فذكر الله باللسان وسيلة

$$
\text { للحضور القلبي ، وهما وسيلتان للقرب و الوصول . }
$$

لكن لتحقيق هذه الغاية لابد من أن يكون الذاكر متأسيا بالنبي للأو امر سائر اعلى النهج النبوي، وليس متبعا لنفسه، وهذا هو شرط القبول الأول. وقد تكلم الحافظ ابن أبي جمرة في هذا الشرط موضحا السنة في الذكر وكيف يجقها العبد مصححا لمن ضلوا الطريق في هذا الباب قائلا : ( وهذا الذكر الذي يبلغ به العبد هذا الحال إنما هو بعد أداء الفرض ؛ لأن ما نحن بسبيله هو كله من

رواه الإمام أحمد في مسنده باللفظ المذكور مرفوعا عن سيدنا معاذ بن جبل ـ ونسبه ابن ماجة والحاكم في المستدرك وغيرهما من قول سيدنا معاذ بن جبل و النص عندهم : (عن أبي الدرداءالله:

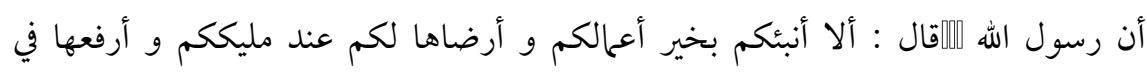
درجاتكم و خير لكم من إعطاء الذهب و الورق و من أن تلقوا عدوكم فتضربون أعناقهم و و ولهيم

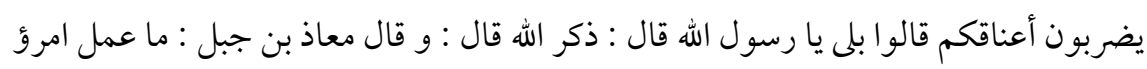
بعمل أنجى له من عذاب اله من ذكر الله) قال البيهقي في شعب الإيهان : و روينا في كتاب

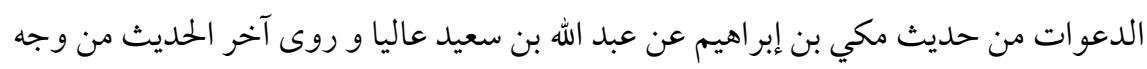

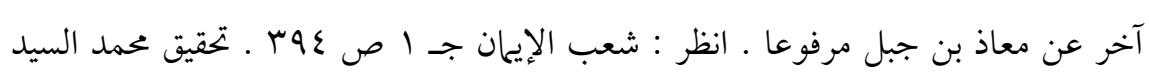

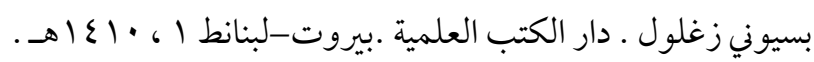

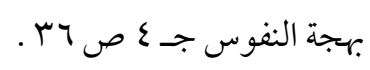




\section{موقف الحافظ ابن أبي جمرة من التصوف}

باب المندوبات ، وجميع المندوب كله لا يقوم بفريضة واحدة فكيف بالمتعددة (1)، وكذلك لم يأخذ القوم في مثل هذه المندوبات حتى أكملوا فروضهم التي هي الأصل في الدين وحينئ أخذو فيما ذكرنا .

وقد وقع بعض الناس في العكس بالسو اء فسمعوا مثل هذا الحديث وشبهه فأكثرو من المندوبات وضيعوا كثيرا من الواجبات ، فصاروا كما قال صاحب

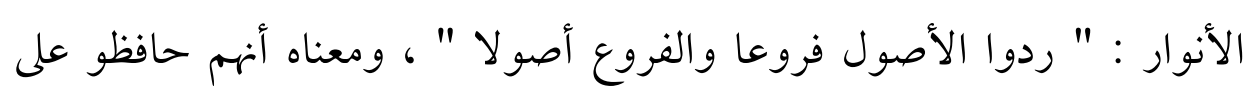
المندوبات كما حافظ أهل التوفيق(r) على الواجبات وزهدوا في الواجبات وتعلقوا في

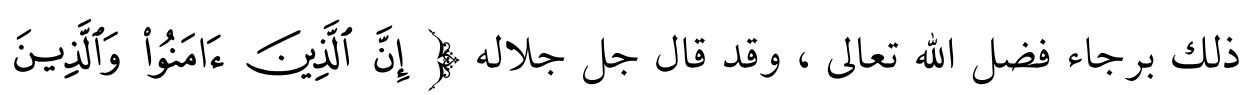

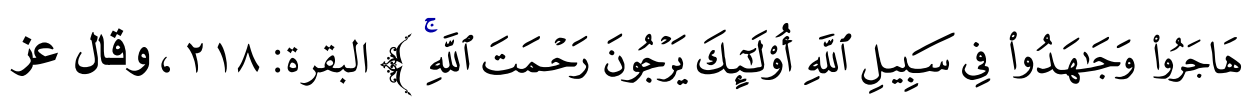

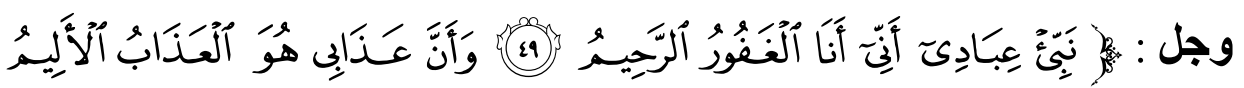

مقصود الحافظ هنا هو الذكر باللسان بالأذكار المعروفة الداخلة في باب النوافل ، وإلا فإن

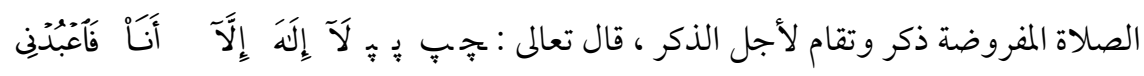

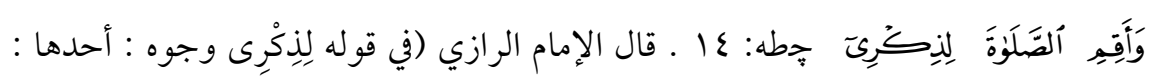

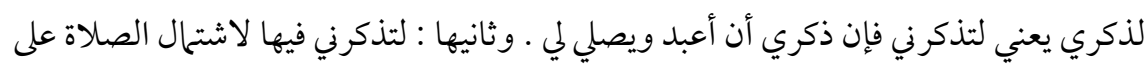

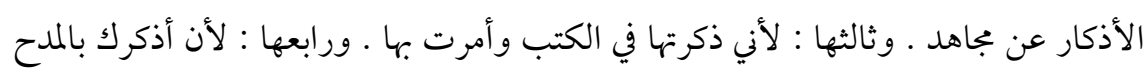
و الثناء واجعل لك لسان صدق ـ وخامسها : لذكري خاصة لا تشوبه بذكر غيري . وسادسها :

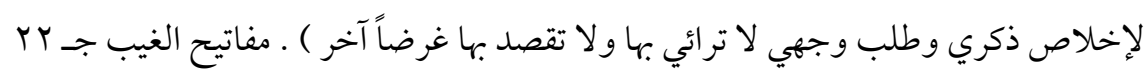

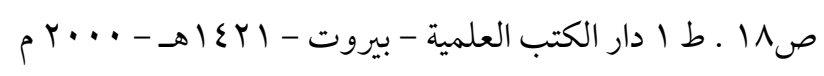

هذا الوصف مدح للفاعل وذم لغيره ، وهو من باب الذم بذكر الضد ، والمعنى : إن كان الفاعل

$$
\text { قدوفق في فعل الطاعات فالتارك مخذول . }
$$




\section{موقف الحافظ ابن أبي جمرة من التصوف}

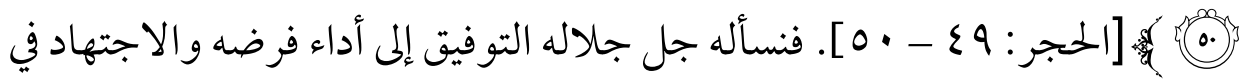
أعحال ما ندبنا إليه وقبول ذلك و السعادة به بمنه لا رب سو اه )(") .

والمقصود من كلام الحافظ أن فعلهم للواجبات قصدهم فيه رضا الله وابتغاء

رحته ، وأنهم طامعون في الرحمة يعولون عليها في القبول وليس على أعمالهم مخافة أن يكون قد شابها رياء أو عجب ، وهم في ذلك مقتدون سنته هريرة أن رسول اله ولا أنت يا رسول الله ؟ قال : ( ولا أنا إلا أن يتغمدني الله برحته ولكن سددوا ) (r) ، وقد أبرز الحافظ هذا القيد لئلا يقال : إنهم عولوا على العمل وأدائه ونسوا رحمة الله تعالى

\section{ثانيا : التربيةالصوفية ودرجاتها}

التربية عند الصوفية وسيلة لتهذيب نفوس المريدين ، ونقلها من خلال

$$
\text { التربية المى أحسن الأحو ال . }
$$

وقد عرفها أستاذنا الدكتور عبداله الشاذلي بأنها : ( تهذيب وتسليك

المريدين بالقصد وتهيئة المناخ لذلك على يد عارف بجرب بغية تعريف السالكين بر.هم ، وتوصيلهم اليه بعد تخليصهم من شرور أنفسهم وأهوائهم

$$
\text { بهجة النفوس جـ ع ص حr. }
$$

أخرجه مسلم في صحيحه : باب : لن يدخل أحد الجنة عمله بل برحمة الله تعالى . جـ ^ ص صـ صله 


\section{موقف العافظ ابن أبي جمرة من التصوف}

(1)

وللصوفية اهتحام كبير بأمر التربية حيث تكلموا في مبادئها ، ووضعوا

ها قو اعد لتسير عليها ، وجعلوها أول درجات السلوكك (r).

ويؤكد الحافظ ابن أبي جمرة هذا المعنى استدلالا بحديث بدء الوحي

(r)فيقول : ( فيه دليل على أن التربية للمريد أفضل من غيرها ؛ لأن النبي

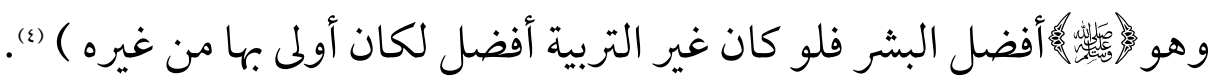

فالتربية لا بد منها للمريد خاصة في بداية سلو كه بعد انتباهه من غفلته ، ويرى الحافظ ابن أبي جمرة أنه لابد من توافر عدد من الأمور حتى تؤتي التربية ثمارها التربوية للمريد.

1.د / عبد الله الشاذلي :التصوف الإسلامي في ميزان الكتاب والسنة جـ ع ص بـ ـ مكتبة

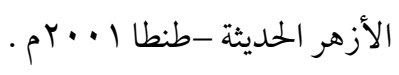

انظر : أبو النجيب السهروردي : آداب المريدين ص ^r . تحقيق : الدكتور / عاصم الكيالي . دار

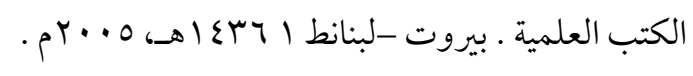

أخرجه الإمام البخاري في صحيحه كتاب بدء الوحي · باب كيف كان بدء الوحي إلى رسول

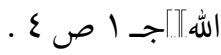

$$
\begin{aligned}
& \text { بهجة النفوس جـ ا ص · 1-11 . }
\end{aligned}
$$




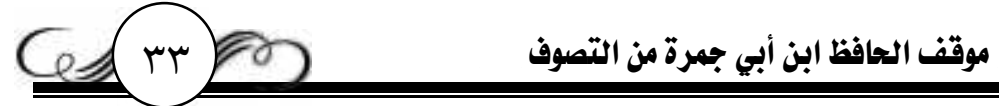

\section{أولا : ضرورة التربية على الكتابوالسنة}

أكد الصوفية مرارا على هذا الأمر ، مؤكدين انه لابد من كل فعل وقول

$$
\text { للمريد وللشيخ معا أن يكون على الكتاب و السنة . }
$$

وسبق حديث الحافظ عن حسن طريق أهل التصوف باتباعهم الكتاب

$$
\text { و السنة وعدم الخروج عنهها . }
$$

والحال كذلك في التربية الصوفية فالمشايخ ومريدوهم تمسكو ابالسنة في

جميع أحوالهم ، وزاد اعتنائهم بها في مسائل الأصول التي ينبغي أن يكونوا عليها في سيرهم إلى الله تعالى ، ومن هذه المسائل التي تستنبط من فكر الحافظ

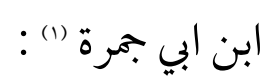

\section{ا - الأخذ بالسنة في اتباعالعلم الشرعي دوز غيره .}

هذا أصل عظيم في التربية الصوفية لكل ما يأتي بعده من مسائل تتعلق بالتربية . ومعلوم أن العلم قسمان : علم مكتسب قائم على دراسة المسائل الشرعية المستنبطة من الكتاب والسنة ، وآخر موهوب يسمى بالعلم اللدني ،

اقتصرت على هاتين المسألتين المذكورتين لسبيين : أولها : أن الحافظ ابن أبي جمرة ذكرهما صراحة

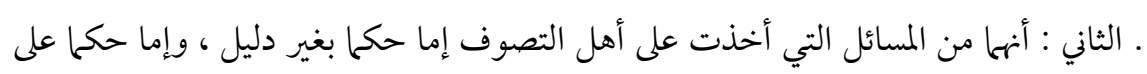

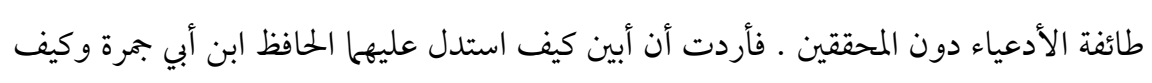

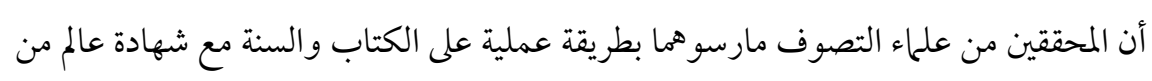
علماء السنة لهم بذلك. 


\section{Cess}

\section{موقف الحافظ ابن أبي جمرة من التصوف}

وهو الذي يهبه الله تعالى لمن يشاء من عباده دون سابق تعلم .

فالنوع الأول ثبتت به مسائل الشرع أصولا وفروعا فلا سبيل لإثباتها

سو اه ، وهو طريق الوصول الذي أكد عليه كبار المحققين من مشايخ الصوفية ، وحذرو من خلافه ، فيقول أبو الحسين الوراق ( 9 اسهـ ) : ( لا يصل العبد إلى الله إلا بالله ، وبموافقة حبيبه الوصول في غير الاقتداء يضل من حيث يظن أنه مهتد ) (1). وقد ذكر الحافظ ابن أبي جمرة أن مشايخ التصوف كانوا يتحققون ويكققون المريدين بالعلم الشرعي ، ويصقلون علومهم بمعرفة الصحيح و الفاسد ويضعونهم على طريق الحت دون زيغ عنه ( فينقل عن بعض فضلاء أهل هذا الشأن إذا خطر له الخاطر يقول : " لا أصدقك حتى تأتيني بدليلين ، دليل من الكتاب ودليل من السنة ؛ لعلمه أن الرباني (r) لا يخالف الكتاب ولا السنة فيجتمع له العمل بالعلمين معا اللدني والشرعي . هذا هو حالهم لا ينفردون أبدا للعمل باللدني حتى يوافقه المنقول فيعملون بها معا ، اللهم إلال عند ضرورة لا يمكن العلم بالو اقع من جهة المنقول ، فيبين لهم العلم في ذلك

السلمي : طبقات الصوفية ص • بr ـ تحقيق : مصطفى عبدالقادر عطا ـ دار الكتب العلمية .

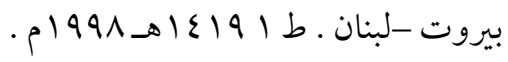

يقصد الخاطر الرباني ، وسيأتي مزيد تفصيل له بعون الله تعالى عند ذكر الخو اطر والتمييز بينها . 


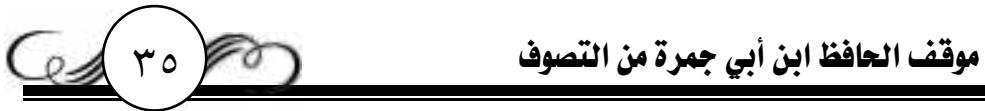

أعني العلم اللدني فيعملون به لا نحتام الوقت عليهم ثم ينظرون في العلم المنقول بعد ذلك فيجدونه مو افقا لما هدوا إليه ) (1).

فالأخذ بالعلم الشرعي في المعرفة والعمل ضرورة لابد من توافرها في الصوفي شيخا كان أو مريدا ، فالصوفية يتعلمون الشرع ويعملون به ، فلا يتركون العمل بالسنة في أمورهم التعبدية ، فهم -أو ينبغي أن يكونو اكذلك -

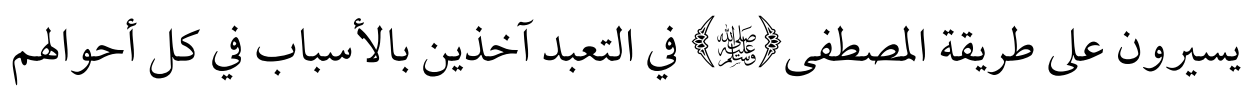
حتى وإن اعتقدوا أن الأسباب غير مؤثرة بذاتها وأن المؤثر في الكون هو الله وحده على الحقيقة (r)، فكان الواحد منهم يتزود بالطعام والشراب في خلوته

$$
\text { بهجة النفوس جـ ا ص 7 ع بتصرف يسير . }
$$

اختلفت الفرق في العلاقة التأثيرية بين السبب والمسبب ، ونقل هذا الاختلاف الإمام البيجوري

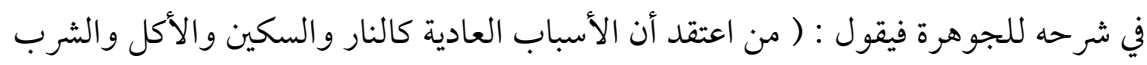
تؤثر في مسبباتها كالحرق والقطع والشبع والري بطبعها وذاتها فهو كافر بالإجماع.أو بقوة خلقها الله فيها ففي كفره قولان، والأصح أنه ليس بكافر بل فاسق مبتدع • ومثل القائلين بذلك المعتزلة القائلون بأن العبد يخلق أفعال نفسه الاختيارية بقدرة خلقها الله فيهفالأصح عدم

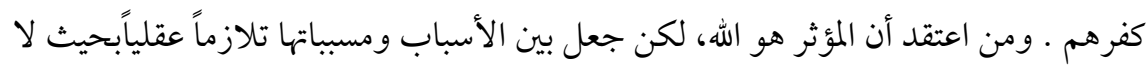
يصح تخلفها فهو جاهل، وربها جره ذلك إلى الكفر، فإنه قد ينكر معجزات الأنبياء لكونها على

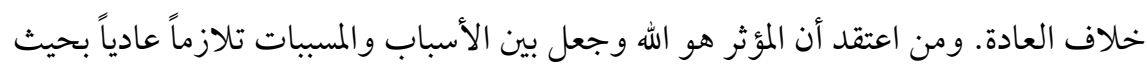
يصح تخلفها فهو المؤمن الناجي إن شاء الله تعالى ـ فالفرق في ذلك أربعة كما يؤخذ من كتب

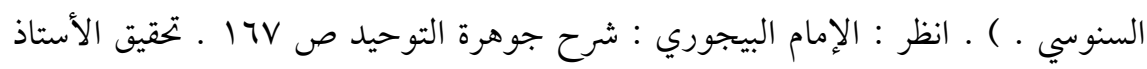

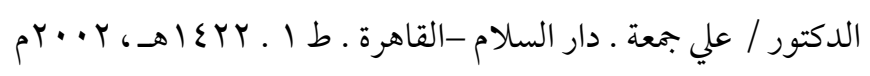




\section{موقف الحافظ ابن أبي جمرة من التصوف}

ورحلاته متأسين بفعله بدء الوحي حين قالت : ( وكان يخلو بغار حراء فيتحنث فيه وهو التعبد الليالي ذوات العدد قبل أن ينزع إلى أهله ويتزود لذلك ثم يرجع إلى خديجة فيتزود لمثلها حتى جاءه الحق ) . وهم في ذلك حريصين على البعد عن الرياء والغرور والعجب بالنفس وذلك ؛ ( لأن الخروج بغير زاد فيه شيء من الادعاء وإن كأن لم ينطق به ، ولم ينو ، فيخاف على فاعل ذلك أن يكله الله لنفسه فيعجز عن توفية ما أراد في وجهته ) (1).

\section{r - الأخذ بالسنة في التبرك.}

التبرك : تفعل من برك وهو طلب البركة التي هي الزيادة والنهاء(r)،

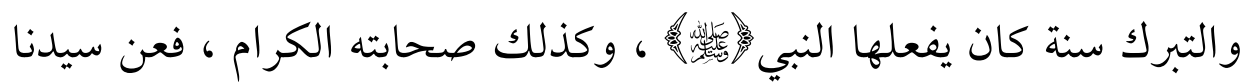
كعب بن مالك فيه )(r) · يقول الحافظ ابن أبي جمرة : ( في الحلديث دليل على التبرك بكل ما جعلت له حرمة وترفع إلا أنه يكون ذلك على لسان العلم فيؤخذ وجه التبرك من كون سيدنا⿳⺈ من الخير ، والدليل على أن ذلك يكون على لسان العلم أنه عي

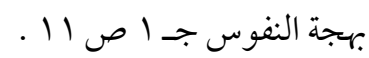

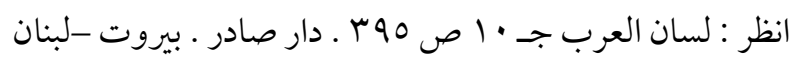

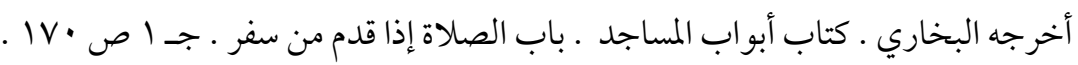




\section{موقف الحافظ ابن أبي جمرة من التصوف}

الصالة التي من أجلها رفع ، فكذلك يلزم في غيره ألا يكون تعظيمه والتبرك به إلا على الوجه المشروع ، ولهذا المعنى كان أهل الصوفة أكثر الناس احتراما لما جعل له حرمة ، وأن يكون ذلك الاحترام على لسان العلم كما تقدم (1) حتى أنه يذكر عن بعض الأكابر منهم أنه دخل المسجد فنسي وقدم رجله اليسار فوقع مغشيا لشدة الحياء من الله لكونه وقعت منه مخالفة السنة في دخول بيته ؛ لأن السنة في دخول المسجد تقديم الرجل اليمين ، وقد قال العلماء : من نسي فقدم اليسار أخرجه وقدم اليمين ، فإنه معذور بالنسيان ، فانظر إلى احترام هذا السيد كيف كان وهو فيما وقع منه معذور على لسان العلم فناهيك عن غيره ) وبهذا يظهر أن الحافظ ابن أبي جمرة يرى أن طريق التصوف في التربية قائم على الكتاب و السنة ، و أن أهله من المحققين هم أكثر الناس اتباعا للسنة ، وأحرص الناس على أدائها ، وأما من خالفها فليس منهم بل هو من الأدعياء المنتسبين ، وهذه قاعدة لكل ما يأتي من مسائل في هذا الباب .

يُلاحَظ أن الشيخ الحافظ ابن أبي جمرة أكد على هذا المعنى أكثر من مرة ، وذلك لأن مسألة التبرك من المسائل التي كثر حولها الجدل قديا وحديثا من حيث مشروعيته وعدمها ، ثم إذا كان مشروعا فكيف يكون ؟ وما هي الأشياء التي يجوز التبرك بها ؟ ومتى يسمى الفعل تبركا ؟

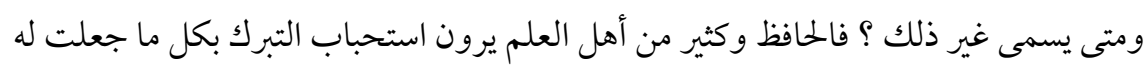
حرمة وبركة لكن بشرط أن يكون ذلك على لسان العلم الشرعي وليس بالهوى .

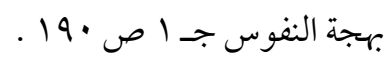




\section{موقف الحافظ ابن أبي جمرة من التصوف}

\section{ثانيا : اتخاذالشيخ المربي}

اتفق الصوفية على أن أول ما يلزم المريد بعد الانتباه من غفلته أن يقصد إلى شيخ ناصح مرشد عليم بعيوب النفس وأغراضها ودواعيها وأدوية أمر اضها ، مؤتمن على دينه ، معروف بالنصح والأمانه ، يبصره بعيوب نفسه ، ويخرجه من دائرة حسه ؛ لأن من لم يكن له شيخ يقوده إلى طريق المدى قاده الشيطان إلى طريق الردى (1) -

وقد استنبط الحافظ ابن أبي جمرة ذلك المعنى من حديث سيدنا عبداله

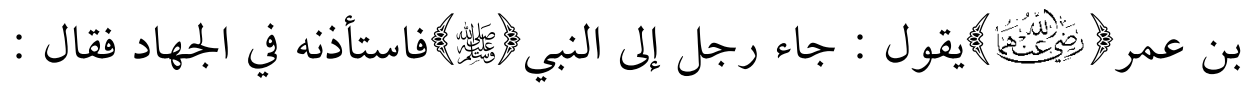
أحي والداك قال : نعم . قال : ففيها فجاهد) (r) . فيقول : ( فيه دليل على أن الدخول في السلوك والمجاهدات السنية فيه أن يكون على يد عارف به فيرشد إلى ما هو الأصلح فيه والأسد بالنسبة إلى حال السالك ؛ لأن هذا الصحابي

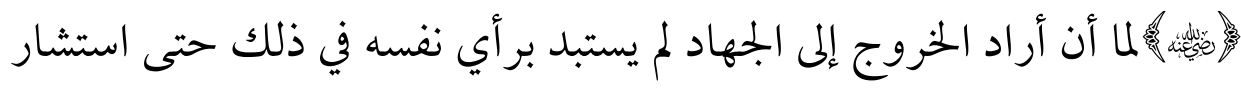
من هو أعلم منه وأعرف (r) ، هذا هو ما في الجهاد الأصغر ، فكيف به في

انظر : آداب المريدين ص ^ץ ـ وانظر : ابن مامين : نعت البدايات وتوصيف النهايات ص ع . دار الفكر بيروت - لبنان .بدون تاريخ .و انظر :التصوف الإسلامي في ميزان الكتاب والسنة جـ

$$
r \varepsilon \cdot \Omega
$$

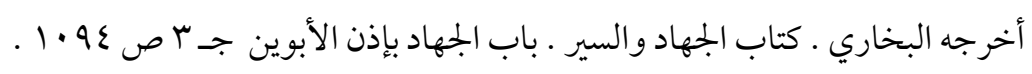

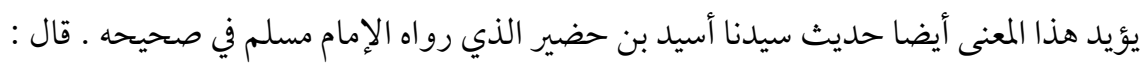




\section{موقف الحافظ ابن أبي جمرة من التصوف}

الجهاد الأكبر • وهذا أدل دليل لأهل الصوفة المتحققين الذين لا يدخلون في المجاهدات و السلوك إلا تحت يد شيخ عارف بالسلوك ويقولون بأن من دخل في ذلك دون شيخ قل أن يجئ منه شيء ، و إن جاء فلا يصل إلى مقام المربي ، ومعرفته وفطنته ، اللهم إن كان ذلك بخرق العادة فليس الكالام عليه وإنما الكلام على ما جرت به عادة الحكمة ) (1). ومقصود كلام الحافظ : أن التربية في العادة لابد أن تكون على يد شيخ عارف ، وهو ما تعارف عليه المسلمون سلفا وخلفا في كل فن من فنون العلوم

= (حدثني حسن بن علي الحلو اني وحجاج بن الشاعر وتقاربا في اللفظ قالا حدثنا يعقوب بن إبر اهيم حدثنا أبي حدثنا يزيد بن الهاد أن عبد الله بن خباب حدثه أن أبا سعيد الخدري حدثه أن

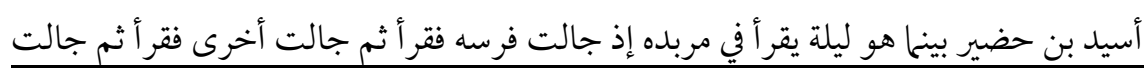
أيضا قال أسيد فخشيت أن تطأ يحيى فقمت إليها فإذا مثل الظلة فوق رأسي فيها أمثال السرج عرجت في الجو حتى ما أراها قال فغدوت على رسول الله لله فقلت يا رسول الله بينها أنا البارحة

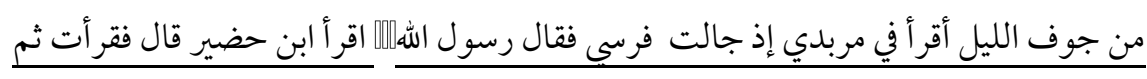
جالت أيضا فقال رسول الله ملها اقرأ ابن حضير قال فقر أت ثم جالت أيضا فقال رسول الله اللهاقرقأ ابن حضير قال فانصرفت وكان يميى قريبا منها خشيت أن تطأه فرأيت مثل الظلة فيها أمثال

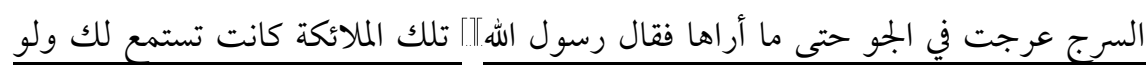
قر أت لأصبحت ير اها الناس ما تستتر منهم) . أخرجه الإمام مسلم في صحيحه ـ كتاب صلاة المسافرين · باب نزول السكينة لقراءة القرآن . جـ r ص ع ع 19 ـدار الجيل بيروت دار الأفاق

$$
\begin{aligned}
& \text { الجديدة-بيروت-لبنان . }
\end{aligned}
$$

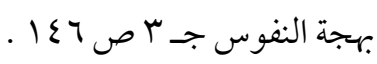




\section{موقف الحافظ ابن أبي جمرة من التصوف}

، وعند كل تربية للسلوك الظاهر أو للأخلاق ، لابد من وجود شيخ عارف يوجه ويرشد وينصح ويبين الخطاً من الصواب ، دأب المسلمون على ذلك

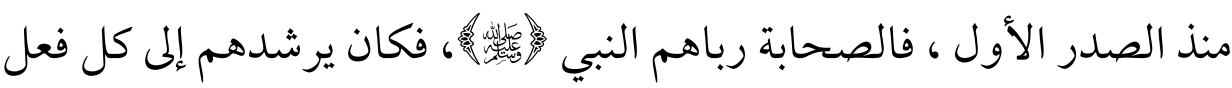
صالح ، وكانوا يسألونه الإجابة ، ثم بعد ذلك قام الصحابة بتربية التابعين وظل الأمر يتتابع حتى يوم الناس هذا ، لا ينكره إلا جاهل دعي مغرور بنفسه يظن أنه قد يتعلم من غير شيخ مربي ·

\section{ثاثثا : التخخلي}

التخلي أحد درجات التربية الصوفية ، يقوم كغيره من مسائل التصوف على الكتاب و السنة حتى يؤتي ثمرته في طريت السير إلى الله تعالى ، وفيه يبدأ المريد بنبذ وترك معوقات السلوك إلى الله تعالى .

\section{تعريف التخلي}

التخلي عند أهل اللغة يعني : التفرغ ، يقال : تخلى للعبادة وهو تفعل من الخلو ، والمراد التبرؤ من الشرك وعقد القلب على الإيهان . وخلى عن الثيء

$$
\text { أرسله وخلى سبيله فهو غخلي عنه (1) . }
$$

والتخلي عند الصوفية يعني : ترك كل ما يشغل عن الله تعالى ، يقول

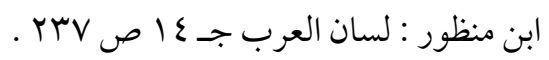




\section{موقف الحافظ ابن أبي جمرة من التصوف}

الطوسي في اللمع : ( والتخلي هو الإعراض عن العوارض المشغلة بالظاهر و الباطن وهو اختيار الخلوة ، وإيثار العزلة وملازمة الوحدة ، وعن يوسف بن الحسين(飞 · r هـ )(رحمه الله تعالى ) في معنى التخلي : قال : هو العزلة ؛ لأنه لم يقو على نفسه وضعف فاعتزل من نفسه لربه )(") .

وقال الإمام القشيري : ( التخلي : اختيار الخلوة والإعراض عن كل

$$
\text { شي شغل عن الحق ) (r) }
$$

\section{منزلة|التخلي في التربية}

يقدم الصوفية التخلي في التربية عن غيره ، وغرضهم في ذلك تصفية محل

المعارف وهو القلب من كل عائق يعوقه عن استقبال المعارف الربانية .

والحافظ ابن أبي جمرة يؤكد ذلك المعنى ، ويستنبط له دليلا من حديث

بدء الوحي ، فيقول : ( في الحديث دليل لأهل الصوفة حيث يقولون : إن التحلي لا يكون إلا بعد التخلي ؛ لأن النبي مجهوده غاية ، فلما أن كان تخليه أفضل وأشرف من تخلي غيره و البشر قاصر عن التخلي لها ، ضمه جبريل

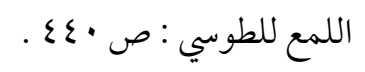

د/ قاسم السامرائي : أربع رسائل في التصوف للقشيري ص به ـ ـ المجمع العلمي بالعراق 


\section{موقف الحافظ ابن أبي جمرة من التصوف}

ولذلك قال : حتى بلغ مني الجهه ؛ لأن التخلي هو ضمه إليه حتى بلغ من جاهدة النفس الغاية ، و التحلي هو إلقاء الوحي إليه ) (1). ويستنبط الحافظ ذلك المعنى أيضا من حديث المعراج الذي يقول فيه

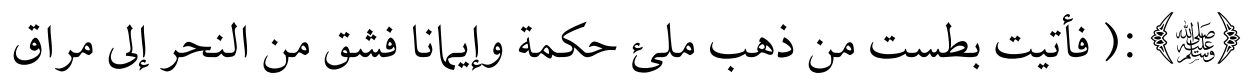
البطن ثم غسل البطن بهاء زمزم ثم ملئ حكمة وإيهانا ) (r). فيقول : ( فيه دليل

$$
\text { بهجة النفوس جـ اص ص } 17 .
$$

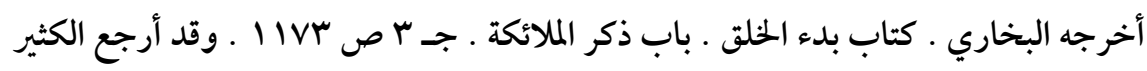

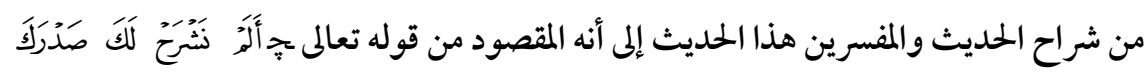
ج [الشرح: 1] يقول الإمام الرازي : ( في شرح الصدر قولان : الأول : ما روى أن جبريل|سلأتاه وشق صدره وأخرج قلبه وغسله وأنقاه من المعاصي ثم ملأه علماً وإيهاناً ووضعه في صدره ـ واعلم أن القاضي طعن في هذه الرواية من وجوه : أحدها : أن الرواية

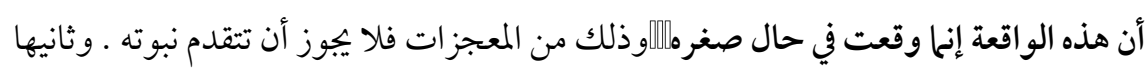
: أن تأثير الغسل في إزالة الأجسام والمعاصي ليست بأجسام فلا يكون للغسل فيها أثر ـ ثالثها : أنه لا يصح أن يملاً القلب علماً بلاله تعالى يخلق فيه العلوم .

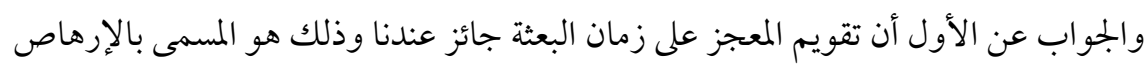

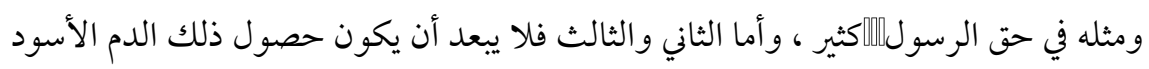
الذي غسلوه من قلب الرسول|الهلامة للقلب الذي يميل إلى المعاصي ويحجم عن الطاعات فإذا

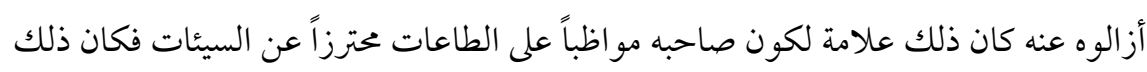

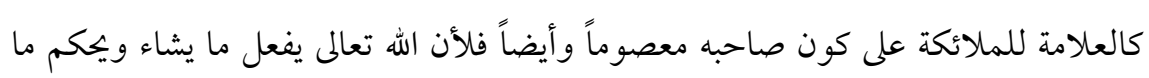
يريد. والقول الثاني : أن المراد من شـرح الصـدر ما يرجع إلى المعرفة والطاعة ثم ذكروا فيه وجوهاً: $=$ 


\section{موقف الحافظ ابن أبي جمرة من التصوف \\ لأهل الصوفة في قوهم " لا يكون تحلي إلا بعد تخلي " ؛ لأنه لم يوضع الإيهان والحكمة في الباطن المباركة حتى شقت وغسلت وحينئ ملئت ، فالشت والغسل هو التخلي ، وما ملئ به من الحلكمة هو التحلي (1) ، فعلى قدر التخلي يكون التحلي (r) (ب)}

= أحدها : أنه الملما بعث إلى الجن والإنس فكان يضيق صدره عن منازعة الجن والإنس والبراءة من كل عابد ومعبود سوى الله فآتاه الله من آياته ما اتسع لكل ما حمله وصغره عنده كل شيء

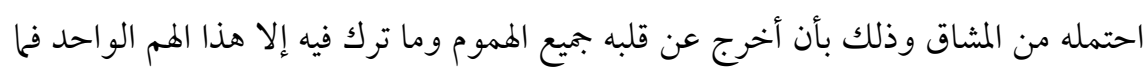
كان يخطر بباله هم النفقة والعيال ولا يبالي بها يتوجه إليه من إيذائهم حتى صاروا في عينه دون

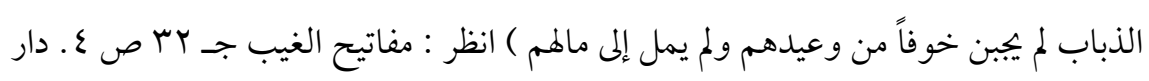

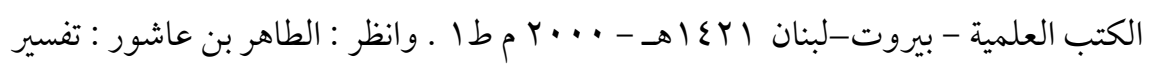
التحرير والتنوير جـ ·r ص م • ع ـ دار سحنون للنشر والتوزيع - تونس - $199 V$ م. م.

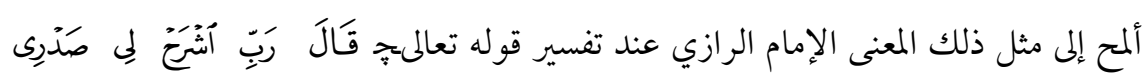

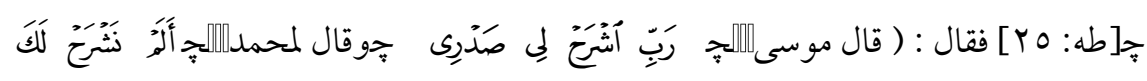

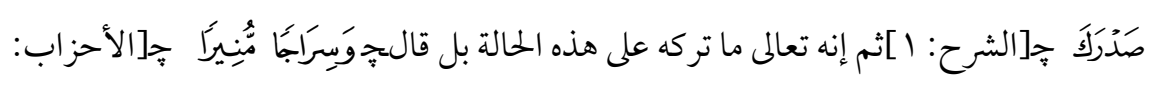

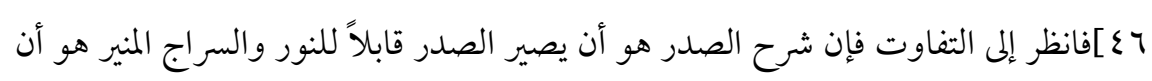

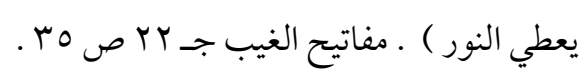

بهجة النفوس جـ r ص INV ـ ـ وقد وقعت حادثة شق الصدر للنبيلمأكثر من مرة ، في صغره

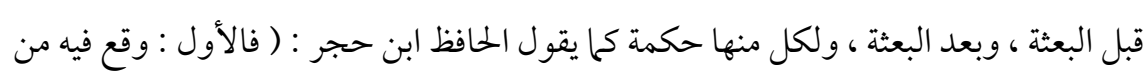

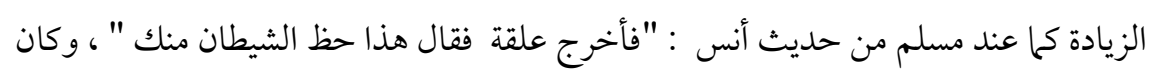

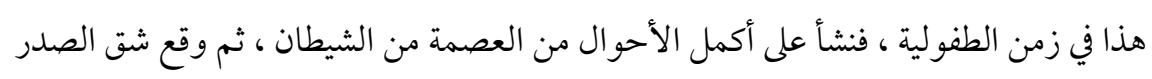
عند البعث ؛ زيادة في اكرامه ليتلقى ما يوحى إليه بقلب قوي في أكمل الأحو ال من التطهير ، ثم الم $=$ 


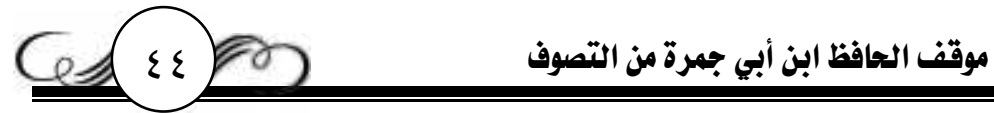

\section{أنواع|التخلي}

يقسم الحافظ ابن أبي جمرة التخلي إلى نوعين : مكتسب وغير مكتسب مستدلا على ذلك بحديث بدء الوحي الذي ورد فيه أنه الغار الليالي ذوات العدد ، وأن سيدنا جبريل قد غطه دليل على أن التخلي على ضربين : مكتسب وفيض من الله تعالى ، فالمكتسب مثل فعل النبي جبريل وضمه له له

فقد يكون من السالكين من تخليه بالكسب لا غير ، وقد يكون تخليه بالفيض لا غير مثل إبراهيم ابن أدهم (1) ، و الفضيل بن عياض (1) وغيرهما ،

= وقع شق الصدر عند إرادة العروج إلى السماء ليتأهب للمناجاة ويحتمل ان تكون الحكمة في هذا الغسل لتقع المبالغة في الإسباغ بحصول المرة الثالثة كما تقرر في شرعهالهل ،ويحتمل ان تكون الحكمة في انفراج سقف بيته الإشارة إلى ما سيقع من شق صدره وأنه سيلتئم بغير معالجة يتضرر

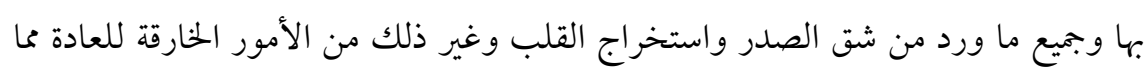
يجب التسليم له دون التعرض لصرفه عن حقيقته لصلاحية القدرة فلا يستحيل شيء من ذلك ونك

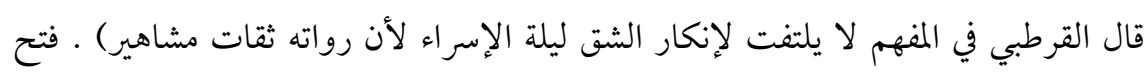

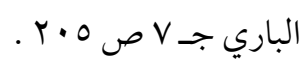

إبراهيم بن أدهم بن منصور بن يزيد بن جابر، القدوة الإمام العارف، سيد الزهاد، أبو إسحاق

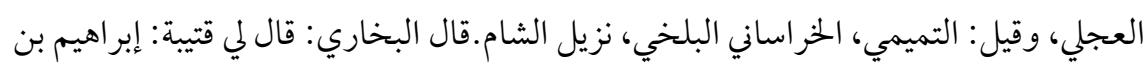

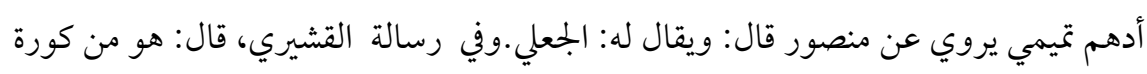
$=$ 


\section{موقف الحافظ ابن أبي جمرة من التصوف}

وقد يجمع لبعضهم الحالتين (r) فيكتسب ويفاض عليه كما فعل للنبي النوعين يعد أكمل حالا من أحدهما وحده .

ف = بلخ، من أبناء الملوك، أثار ثعلبا أو أرنبا، فهتف به هاتف: ألهذاخلقت ؟ أم بهذا أمرت ؟ فنزل، وصادف راعيا لأبيه، فأخذ عباءته، وأعطاه فرسه، وما معه، ودخل البادية، وصحب الباء الثوري ، والفضيل بن عياض ، ودخل الشام، و كان يأكل من الخصاد وحفظ البساتين ـانظر :

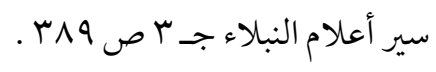

الفضيل بن عياض ابن مسعود بن بشر، الامام القدوة الثبت، شيخ الاسلام، أبو عليالتميمي

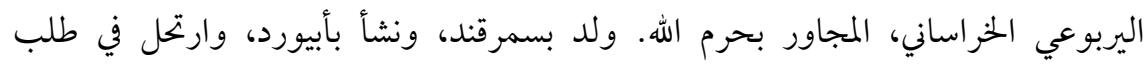

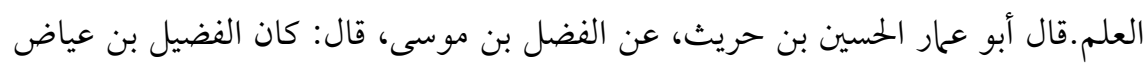

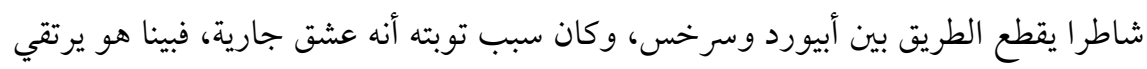

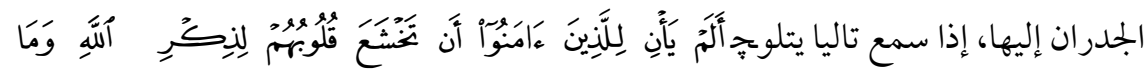

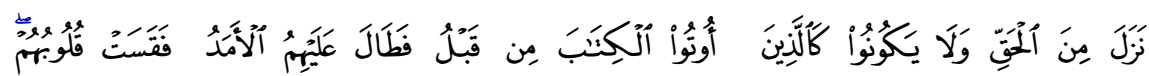

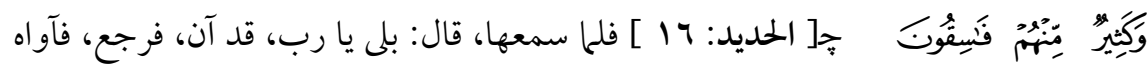
الليل إلى خربة، فإذا فيها سابلة، فقال بعضهم: نرحل، وقال بعضهم: حتى نصبح فإن فضيلا

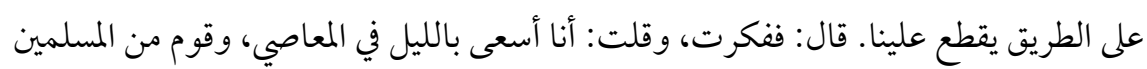

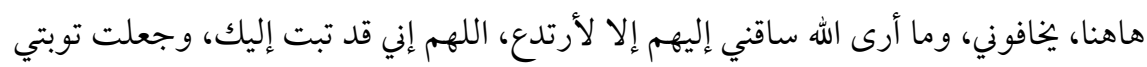

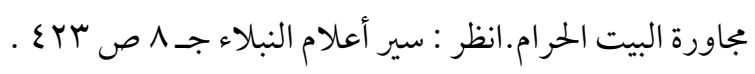

و هذه هي حال الكمال بأن يجمع له التخلي المكتسب والفيض من الله تعالى .

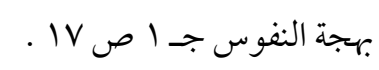




\section{موقف الحافظ ابن أبي جمرة من التصوف}

\section{التخلي المكتسب}

يقوم التخلي المكتسب على عدد من المسائل مكملة لبعضها ، فلابد للسالك منها جملة واحدة بحيث لاينفك أحدها عن الآخر ولا يعرف لها ترتيب مستقل غالبا ، ، ونلمح من فكر الحافظ ابن أبي جمرة أن التخلي المكتسب يشتمل على ثلاثة مسائل رئيسية وهي

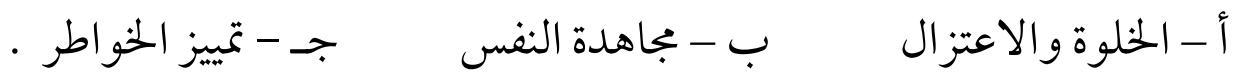

\section{أولا : الخلوةوالاعتزال}

الخلوة على الحقيقة هي : ( محادثة السر مع الحق بحيث لايرى غيره ، و أما صورتها فهو ما يتوصل به إلى هذا المعنى من التبتل المى الله تعالى والانقطاع عن غيره )(") . (والخلوة أخص من العزلة، وهي بو جهها وصورتها نوع من الاعتكاف، ولكن لا في المسجد، وربها كانت فيه، وأكثرها عند القوم لا حدَّ له، لكن السنة تشير للأربعين بمواعدة موسى ( عليه السلام ) ، و القصد في الحقيقة :الثلاثون، إذ هي أصل المواعدة، وجاور عليه الصلاة والسلام بحراء شهراً ، وكذا اعتزل نساءه، وشهر الصوم واحد. وزيادة القصد ونقصانه كالمريد في سلو كه. وأقلها عشرة لاعتكافه عليه الصالاة والسالكم للعشر، وهي للكامل زيادة في حاله، ولغيره ترقية، و لا بد من أصل يُرجع إليه) (r).

ابن عطاء الله السكندري : مفتاح الفلاح ومصباح الأرواح ص Vr . تحقيق : محمد عبدالسلام

$$
\begin{aligned}
& \text { إبراهيم ـ دار الكتب العلمية ـ بيروت -لبنان . } \\
& \text { قو اعد التصوف ص VV }
\end{aligned}
$$




\section{موقف الحافظ ابن أبي جمرة من التصوف}

وللخلوة غاية لأجلها شرعت وهي (تطهير القلب من أدناس

الملابسة، وإفراد القلب لذكر واحد، وحقيقة واحدة، ولكنها بلا شيخ خخطرة، ولها فتوح عظيم، وقد لا تصح بأقوام، فليعتبر كل أحد بها حالَه ) (1).

فللخلوة في باب التخلي منزلة عظيمة ، ولجل ذلك فإن الحافظ ابن أبي جمرة يرى أن الخلوة هي الأولى في البداية وأنها عون للإنسان على العبادة والصلاح. ففي حديث بدء الوحي : ( دليل على أن الأولى بأهل البداية الخلوة والاعتزال ؛ لأن النبي قدر له لم يفعل ذلك ، وبقى يتحنث بين أهله، وصار حاله إلى انه إذا سجد

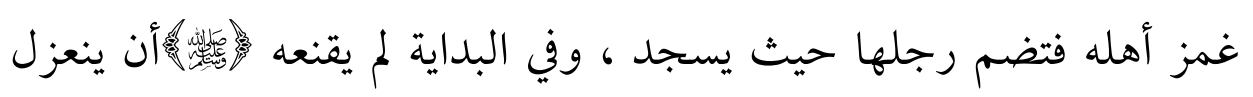
عنهم في البيت حتى خرج إلى الغار .

وفيه دليل على أن الخلوة عون للإنسان على تعبده وصلاح دينه ؛ لأن النبي

$$
\text { نفسه . }
$$

قد يظن أن الحافظ ابن أبي جمرة يقول باكتساب النبوة ـ لكن حقيقة الأمر غير ذلك فهو يقصد أن

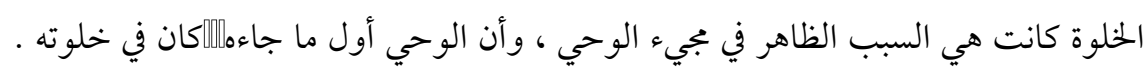

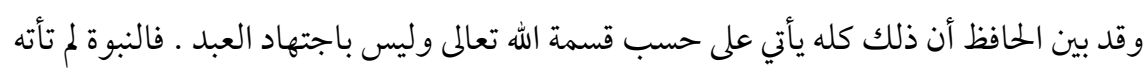

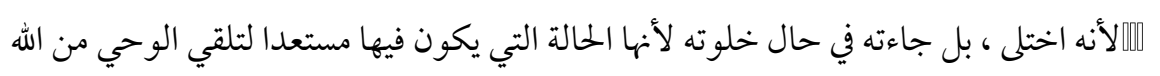

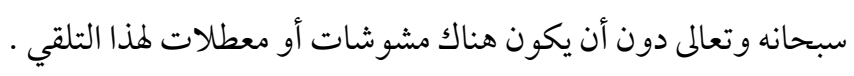




\section{موقف الحافظ ابن أبي جمرة من التصوف}

أحد إذا امتثل ذلك أتاه الخير بحسب ما قسم الله له من مقامات الو لاية ) (1). والخلوة : (كناية عن انفر اد الإنسان بنفسه ) (r) وهي تفترق عن التحنث ( فالخلوة نفسها عبادة فإن زيد عليها من الطاعات فهو التحنث ، ومعنى التحنث التعبد فهو نور على نور ) (r)

\section{شروطالخلوة}

تحدث الحافظ ابن أبي جمرة عن الواجب فعله في الخلوة حتى تكون على الهدي النبوي ، مستدلا على كلامه بنصوص من حديث بدء الوحي . وهذه الأمور هي بمثابة شروط للخلوة حتى تكون صحيحة بحسب الشرع فتؤتي ثمارها بإذن الله تعالى.

\section{الشرطالأول : التسبب في الزاد عند دخول الخلوة}

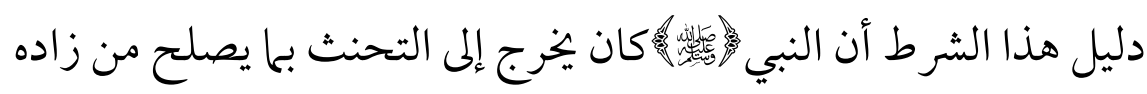

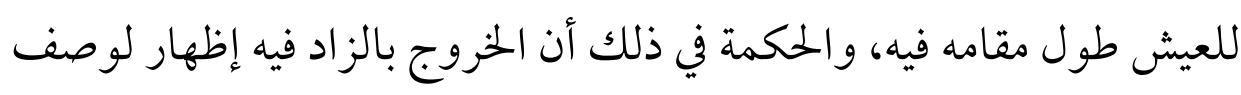
للعبودية وافتقارها وضعفها ؛ لأن المرء أبدا ليس له قوة على تلك المور إلا بإعانة من الله سبحانه وتعالى ، والخروج بغير زاد فيه شيء من الادعاء وإن كان

$$
\begin{aligned}
& \text { بهجة النفوس جـ اص ص ال. } 11 . \\
& \text { المرجع السابق نفسه جـ ا ص } 9 \\
& \text { المرجع السابق نفسه . }
\end{aligned}
$$




\section{موقف الحافظ ابن أبي جمرة من التصوف}

لم ينطق به ولم ينو فيخاف على فاعل ذلك أن يكله الله لنفسه فيعجز عن توفية

$$
\text { ما أراد في وجهته ) (1) }
$$

\section{الشرطالثاني : إعلام الأهل بهوضع الخلوة}

ودليله أنه

$$
\text { بخروجه ، و الحكمة في ذلك من وجوه : }
$$

الوجه الأول : أنه معرض هو وأهله لما يطر أ من الأمراض وغيرها من

الأعراض فإذا كان للأهل علم بموضعه علموا إلى أين يذهبون إليه إذا طرأ شيء من ذلك.

الوجه الثاني : أن في إخبار الأهل بذلك إدخال سرور عليهم وإزالة للوسو اس عنهم ؛ لنهم يتوقعون مصيره إلى مو اضع خختلفة ممكنة فإعلامه لهم بذلك إزالة لما ذكرناه وإدخال السرور عليهم لكونهم يعلمون أنه منقطع للتعبد ومشغول به، وفي إدخال السرور من الأجر والثواب العظيم ما قد علم . الوجه الثالث : ما في ذلك من الدعوة للأهل والإخوان وإن كان لم يطلب ذلك منهم ؛ لأن الغالب من النفوس الانبعاث لما يتكرر عليها من

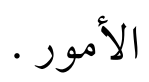

الوجه الرابع : أن من عرفه منقطعا للتعبد ومشغو لا به فإن أراد صحبته

$$
\text { بهجة النفوس جـ الص11. }
$$




\section{موقف الحافظ ابن أبي جمرة من التصوف}

على ما هو بسبيله من غير أن يدخل عليه خللا في طريقه ، ومن أراد غير ذلك لم يصحبه فاستراح منه وز ال عنه ما يلحقه من التشويش في خخالطته ) (1).

\section{الشرطالثا لث : الخلوة تكوز بعد الوفاء بالدقوق والواجبات}

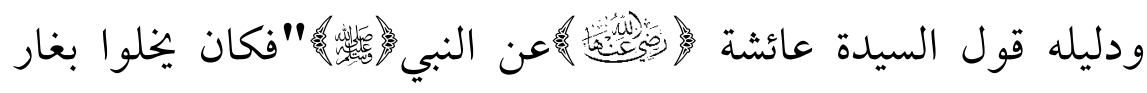

حراء فيتحنث فيه وهو التعبد الليالي ذوات العدد قبل أن ينزع إلى أهله ، تريد قبل أن يرجع إليهم فما يزال أهله ". (r)( وفي هذا دليل على أن العبادة لا تكون إلا بعد إعطاء الحقوق و الواجبات وتوفيتها ؛ لأنه غيره من الحقوق يجب إعطاؤه وتوفيته وحينئ يرجع إلى المندوبات ) (r).

\section{الشرطالرابع : علدمالانقطاعالدائم للخلوة}

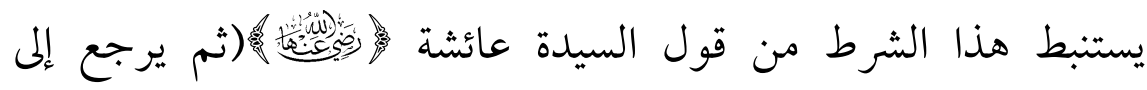
خديجة الدائم ليس من السنة ؛ لأنه كان

$$
\begin{aligned}
& \text { لضروراتهم ثم يخرج لتحنثه ) (s). }
\end{aligned}
$$

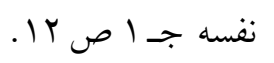

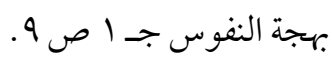

$$
\begin{aligned}
& \text { بهجة النفوس جـ ال ص •1. } \\
& \text { بهجة النفوس جـ ا ص } 9 .
\end{aligned}
$$




\section{موقف الحافظ ابن أبي جمرة من التصوف 012010}

وبذلك يظهر أن الخلوة مستحبة لأهل البداية لأن فيها من التأمل والتفكر ما يعين على تصفية القلب وتنقية السريرة من أدرانها التي تعيق عن الوصول إلى الله تعالى ـ لكن هذه الخلوة لابد أن تكون وفق المشروع في سنته

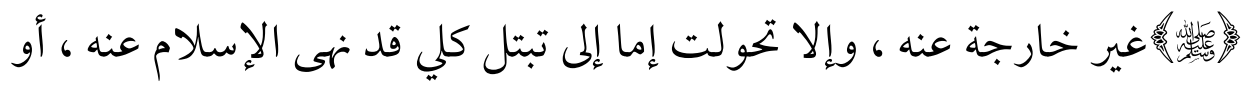
تكون خلوة يسيطر فيها الشيطان على العبد فيعيقه عن الوصول إلى الله تعالى .

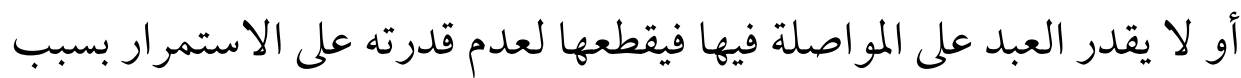

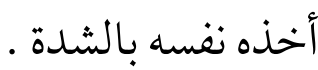

\section{ثانيا : مجا هلدة النفس}

المجاهدة ( بذل المستطاع في أمر المطاع، وقيل: ألا تدع ميسور إلا بذلته ولا تترك مأمور إلا نازلته. وقيل: خلع الراحة وأن يُكسر من القلب جماحه ) (1). وجهاد النفس جزء أصيل وهام في التربية الصوفية وهو يندرج تحت مسائل التخلي ؛ ذلك لأن النفس كما أخبر سبحانه على لسان سيدنا يوسف أمارة بالسوء إلا من رحم الله ، فالإنسان المسلم يحتاج إلى مجاهدتها فيما تأمر به خالفا للشرع ، ويظل كذلك حتى تصير نفسه مطمئنة ، وبذلك يكون الإنسان كيسا عاقلا وليس عاجزا ، كما قال بعد الموت ، و العاجز من أتبع نفسه هو اها ثم تمنى على الله ) (r).

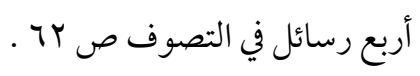

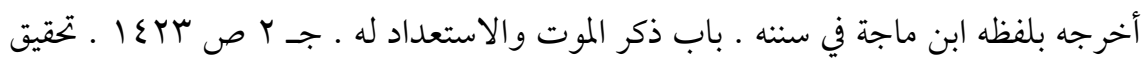

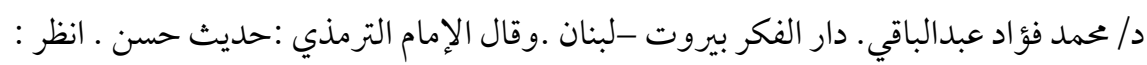
$=$ 


\section{Cof موقف الحافظ ابن أبي جمرة من التصوف}

ولأن للنفس هذا الخطر العظيم فقد اهتم الصوفية بمجاهدتها اهتماما

كبيرا تفوقوا فيه على غيرهم، ورجح بها طريقهم كما قال الحافظ ابن أبي جمرة :

( لأنهم بنوا طريقهم على ترك حظوظ النفس وحمل الأذى وترك الأذى

و إدخال السرور ) (1) - (2)

وقد استنبط الحافظ ابن أبي جمرة من قوله

أفضل من العمل في هذه ) . قالوا ولا الجهاد ؟ قال ( ولا الجهاد إلا رجل خرج يخاطر بنفسه وماله فلم يرجع بشيء )(r) دليلا على ججاهدة النفس ؛ لأنهم يقولون : لا تبلغ الأحوال النفيسة إلا بإذهاب النفس النفيسة، والمخاطرة في المجاهدات بها تبلغ الغايات )

فالترقي مرهون بالتخلي ، والتخلي مقرون بمجاهدة النفس وعدم اتباع

$$
\text { (الموى . (2) }
$$

= سنن الترمذي جـ ع ص ^با7 ـ تحقيق الشيخ أحمد شاكر وآخرون .دار إحياء التراث العربي

$$
\text { بهجة النفوس جـ ب ص لبنان . } 0 .
$$

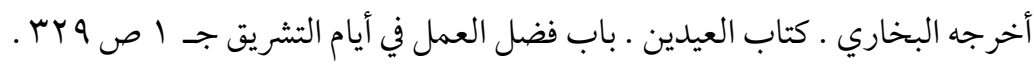

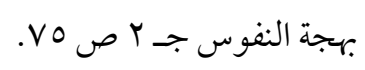

قال الإمام القشيري في الرسالة : ( قال أبو بكر الطمستاني (• ع بهـ) : النعمة العظمى : الخروج

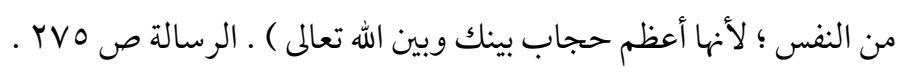


يرى الصوفية مخالفة النفس جملة واحدة ؛ لأنها تشتهي كل معصية ،وفي ذلك المعنى يقول ذو النون المصري ( ع ب هـ ) : ( لا تصحب مع الله إلا بالمو افقة ، ولا مع الخلق إلا بالمناصحة ، ولا مع النفس إلا بالمخالفة ، ولا مع

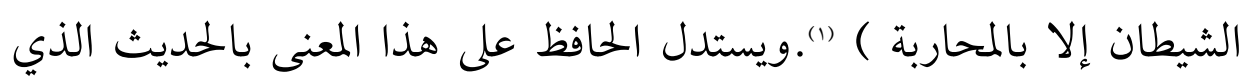
أخرجه الإمام البخاري بسنده عن ابن عباس قال ما رأيت شيئا أشبه باللمم

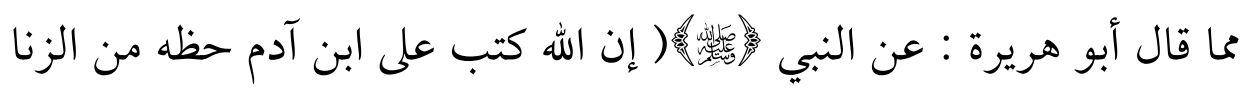
أدرك ذلك لا محالة فزنا العين النظر وزنا اللسان المنطق والنفس تتمنى وتشتهي والفرج يصدق ذلك كله أو يكذبه ) ((r)فهاد النفس أمر ضروري( يؤخذ ذلك من نصه الحرام وتشتهيه ، فمن هذه صفتها وجبت خخالفتها عقلا ودينا ؛ لأنها تفضي بصاحبها للههلاك (r)

\section{حياة النفوس مخالفتها}

يدلل الحافظ ابن أبي جمرة على هذا المعنى مستندا لحديث المسيء صلاته

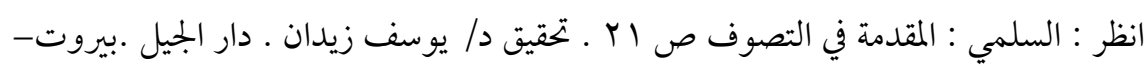

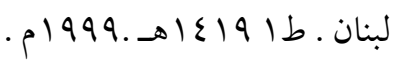

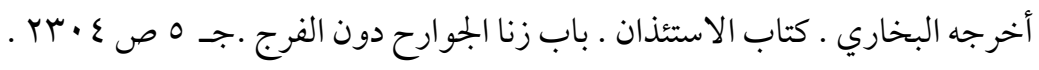

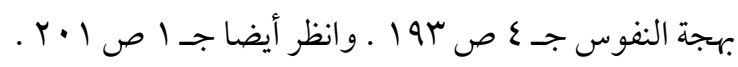




\section{Co موقف الحافظ ابن أبي جمرة من التصوف}

الذي أخرجه الإمام البخاري بسنده عن أبي هريرة: المسجد ورسول الله فقال له رسول الله فصلى ثم جاء فسلم فقال ( وعليك السلام فارجع فصل فإنك لم تصل ) . فقال في الثانية أو في التي بعدها علمني يا رسول الله فقال ( إذا قمت إلى الصلاة فأسبخ الوضوء ثم استقبل القبلة فكبر ثم اقرأ بها تيسر معك من القر آن ثم اركع حتى تطمئن راكعا ثم ارفع حتى تستوي قائحا ثم اسجد حتى تطمئن ساجدا ثم ارفع حتى تطمئن جالسا ثم اسجد حتى تطمئن ساجدا ثم ارفع حتى تطمئن جالسا ثم افعل ذلك في صلاتك كلها ) . فيقول : ( فيه دليل لأهل الصوفة ؛ لأن فضيحة النفس بها فيها موت لها ، وموتها حياتها ـ موت النفس حياتها ، من أحب أن يحيا يموت ) (1). يؤخذ ذلك من فعل الصحابي لما أقر بالخطاً وفضح عيب نفسه أحياها بمعرفة الحقيقة ، ولو أنه لم يعترف ولم يسأل لظل على حالته الأولى ، ولم يتعلم من النبي ولم يكشف له حجاب المعرفة ، ولذلك يقول الصوفية : ( إن الحجب كلها من أنفسهم فمن صح له الخروج الكلي عنها فقد وصل وعرف ) (r) . وقد نقل

$$
\text { انظر : بهجة النفوس جـ r ص IV }
$$




\section{موقف الحافظ ابن أبي جمرة من التصوف}

(قال الإمام القشيري العديد من الأقوال التي تدل على هذا المعنى ومنها الجنيد: أرقت ليلة، فقمت إلى وردي، فلم أجد ما كنت أجده من الحلاوة والتلذذ بمناجاتي لربي، فتحير، فأردت القيام بها لم أقدر عليه، فقعدت، فلم أطق القعود، فقتحت الباب، وخرجت، فإذا رجل ملتف في عباءة مطروح على الطريق. فلما أحس بي، رفع رأسه، وقال: يا أبا القاسم، إلى الساعة فقلت: يا سيدي من غير موعد؟ فقال: بلى قد سألت محرك القلوب أن يحرك إلى قلبك. فقلت: فقد فعل فما حاجتك؟ فقال: متى يصير داء النفس دواءها؟ فقلت: إذا خالفت النفس هو اها صار داؤها دواءها.

فأقبل على نفسه، وقال: اسمعي، قد أجبتك بهذا الجمواب سبع مرات فأبيت أن تسمعيه إلا من الجنيد، فقد سمعت، وانصرفت عني ولم أعرفه. ولم أقف عليه بعد. - أق

وقال أبو بكر الطمستاني: النعمة العظمى: الخروج من النفس؛ لأنه أعظم حجاب بينك وبين الله عز وجل.

وقال سهل بن عبد الله: ما عبد الله بشيء مثل مخالفة النفس والهوى)(1).

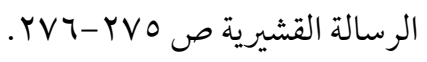




\section{موقف الحافظ ابن أبي جمرة من التصوف}

\section{ثالثا : تقييز الخواطر}

الخاطر ( خطاب يرد على الضمائر ) (1)، وللخواطر في باب العبادات خطر عظيم ، فهي سبيل تدخل الشيطان بالوسوسة و إفساد العبادات . وقد اعتى الصوفية بالخواطر أشد اعتناء؛ وذلك لتمييز بعضها عن بعض • وتمييز الخواطر داخل في باب التخلي السابق للتحلي ، فالخو اطر منها ما هو سيء ينبغي التخلي عنه مطلقا حتى يصير العبد مهيئا للتحلي بالخواطر الحسنة . - | (2)

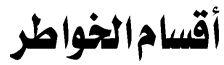

اختلف الصوفية في تحديد الخواطر ، فعدها الإمام عبدالقادر الجيلاني ستا ، وهي عنده : خاطر الشيطان ،وخاطر الروح، وخاطر الملك، وخاطر العقل ، وخاطر اليقين ( فخاطر النفس يتناول الشهوات ومتابعة الهوى المباح منه والجناح ، وخاطر الشيطان يأمر في الأصل بالكفر والشرك والشكوى والتهمة لله عز وجل في وعده ، وفي الفزع بالمعاصي والتسويف بالتوبة ، وما فيه هلاك النفس في الدنيا والآخرة ـ فالخاطر ان مذمومان محكو مان لها بالسوء

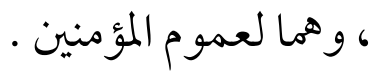

الشيخ / عمد المرصفي : داعي الفلاح ص ..1 . تحقيق : د/ عاصم الكيالي ملحق بكتاب

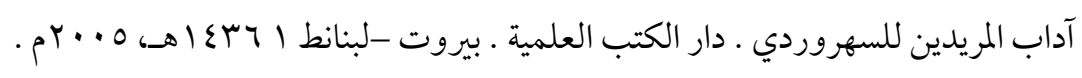




\section{Cov موقف الحافظ ابن أبي جمرة من التصوف}

وخاطر الروح وخاطر الملك : يردان بالحق والطاعة لله عز وجل ، وما

يكون عاقبته سلامة الدنيا والآخرة ، وما يوافق العلم · فها حمودان لا يعدمها خصو ص الناس .

وأما خاطر العقل ، فتارة يأمر بها تأمر به النفس والشيطان ، وأخرى بها يأمر به الروح والملك ، وذلك حكمة من الله وإتقان لصنعه ، ليدخل العبد في الخير والشر بوجود معقول ، وصحة شهود وتميز ، فيكون عاقبة ذلك من الجز اء عائدا له وعليه .

وأما خاطر اليقين ، وهو روح الإيهان ومورد العلم ، فيرد من الله تعالى ويصدر عنه )(') . وعدها الشيخ حمدد المرصفي (977هـ )خمس خو اطر وهي : خاطر الخق ، وخاطر الملك ، وخاطر القلب ، وخاطر النفس ، وخاطر • (r) الشيطان

الشيخ عبدالقادر الجيلاني : الغنية لطالبي طريق الحق جـ ا ص ع •r-O• • . تحقيق : أبو

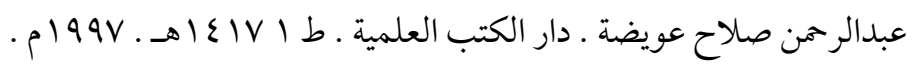
يقول الشيخ محمد المرصفي: ( الخاطر خطاب يرد على الضمائر ، فقد يكون بلقاء الحق ، وتارة

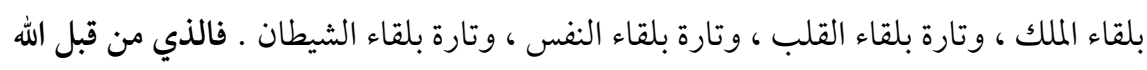

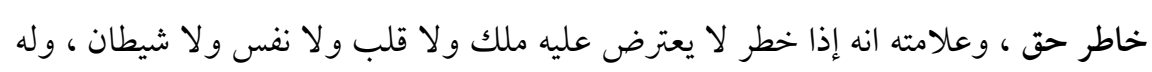

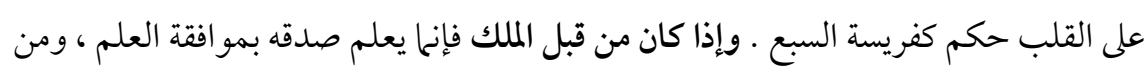
هنا قيل : كل خاطر لا يشهد له ظاهر فهو باطل ، وعلامته انه يجب لمحمودك أبدا مع كراهية

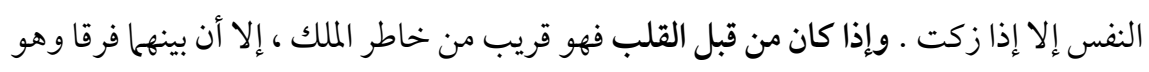
$=$ 


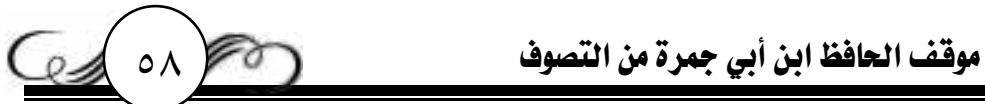

وأقر الحافظ ابن أبي جمرة هذا الاختلاف ورأى أن الخواطر تعود الى

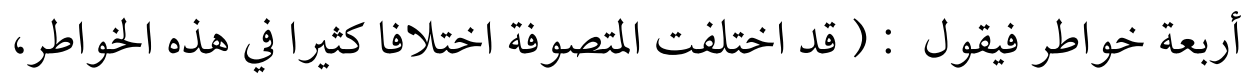
وأحسن ما قيل فيها وألخصه أن الخو اطر على أربعة أقسام : نفساني وشيطاني وملكي ورباني ، فالرباني أولها ، وهو مثل لمحة البرق ولا يثبت ، يليه النفساني ، و الشيطاني و الملكي ) (1)

\section{كيفية تقييزالخواطر}

وضع الحافظ ابن أبي جمرة شروطا لابد منها في الحكم على الخو اطر حتى

يتم التمييز بينها ليعرف الصحيح من الفاسد ، وهذه الشروط منها ما هو في ذات الإنسان إذا أراد التمييز بين الخو اطر بنفسه ، ومنها ما هو خارج عنه إذا

= ان القلب تفارقه في الشهوة ، والشوق ، والحنين و الطيش ، و الطيران ، والإنصاف والمحبة و الرغبة ، والعشق والوله ، والجنون في الحق ؛ وهذا سبب ترجيح المؤمنين على الملائكة ، وأما

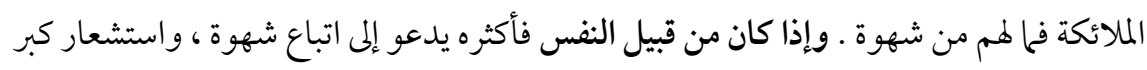

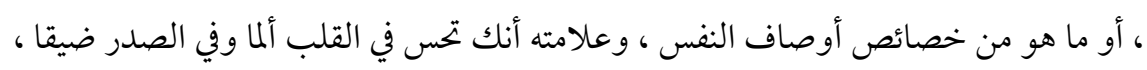
وفي الأعضاء وجعا ، وفي النفس خيفة ، وربها يذهب ويعود حتى تبلغ مرادها ـوإذا كان من قبل

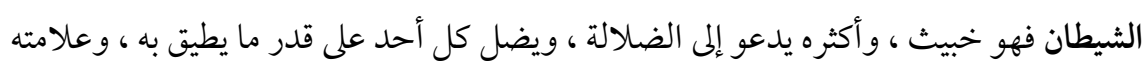
إذا خطر يستفز ويستعجل ، ولا يجد القلب منه راحة ، و كأنك استقبلت الظلمات ، ويمازجك الرياء والالتفات إلى غير الحق وتندق أعضاؤه عند نزوله عليك وقد سموا ما كان من قبل الحق خطابا ، ومن قبل الملك إهاما ، ومن قبل القلب هاتفا ، ومن قبل النفس هاجسا ، ومن قبل

$$
\begin{aligned}
& \text { الشيطان وسواسا ) . داعي الفلاح ص . . 1 - . 1 . }
\end{aligned}
$$

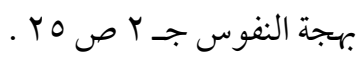




\section{موقف الحافظ ابن أبي جمرة من التصوف 09}

أراد التمييز بغيره . - اد.

ففي ذاته لابد ( أن يكون علمه على الكتاب و السنة خالصا من الشو ائب ، صادقا في توجهه ، عارفا بالخو اطر صالحها وفاسدها معرفة كلية ؛ لأن علم

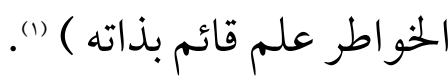

أما إذا لم تكن فيه هذه الشروط فلابد أن يعرض تلك الخو اطر على شيخ مجرب عالم بأحوال الخواطر ( ولأجل ذلك أخذ الفضلاء والعارفون بها العهد على المبتدئين للسلوك ألا يخفو اكل خاطر يرد عليهم كائنا ما كان ؛ ليبينو الهم تلك الخواطر الفاسدة والصالحة وما فيها بعد المشاهدة والعيان ) (م). ( ومن ذلك ما حكي عن بعض الفضلاء منهم أعني الفضلاء المحققين أنه أتاه شخص يريد السلوك ، فأدخله للخلوة وتركه أياما ثم دخل عليه ، وقال له : كيف ترى صورتي عندك ؟ فقال: صورة خنزير ، فقال الشيخ : صدقت ، ثم تركه في خلوته أياما ثم دخل عليه وسأله مثل الأولى فقال له : صورة كلب م كذلك إلى أن قال له صورة القمر ليلة كماله فقال له صدقت الآن كمل حالك وحينئذ أخرجه من الخلوة ، ولا ذاك إلا أن النفس إذا كانت في رعونتها وشهو اتها مثل المرآة الصدئة فإذا أخذ صاحبها في المجاهدة فهي

$$
\begin{aligned}
& \text { بهجة النفوس جـ اص VI . } \\
& \text { نفسه جـ ا ص ^ع . }
\end{aligned}
$$




\section{موقف الحافظ ابن أبي جمرة من التصوف}

صقالة له كصقالة الصقال للمرآة ، فقبل أن تتم صقالتها إذا قابلتها الأشياء وقع المثال فيها مفسودا لبقاء بعض الصدأ فيها فإذا تمت صقالتها وارتفع عنها ذلك الصدأ كله ظهر فيها مثال الأشياء من غير زيادة ولا نقصان ورجعت تميز كل خاطر بحدته لصفائها ) (1) ومن هذا المنطلق فإن الصادقين من أهل هذا الشأن ( إذا خطر له الخاطر يقول: لا أصدقك حتى تأتيني بدليلين، دليل من الكتاب ودليل من السنة ) (r). فالتمييز بين الخواطر له شأن عظيم في التخلي وذلك ؛ ( لأن من لا لا يعرف هذا الشأن سبق إليه الخواطر النفسانية والشيطانية والملكية فيعمل على كل خاطر يخطر له منها ولا يفرق فيها بين الصالح والفاسد فيكون في عمى

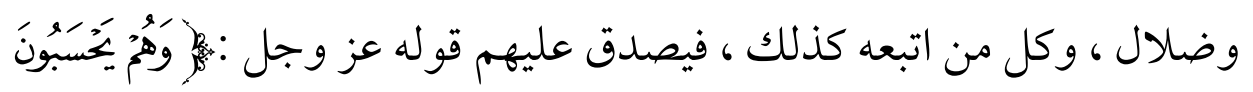

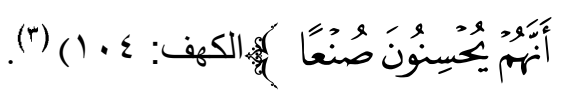
رابعا : التحلي

يعرف الصوفية التحلي بانه : ( التشبه بالصادقين بالأقوال ، وإظهار الأعمال ) (s). ويفرق الشيخ ابن عجيبة بين التخلي والتحلي بقوله : ( التخلية

$$
\begin{aligned}
& \text { نفسه . }
\end{aligned}
$$

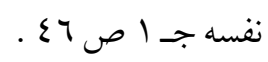

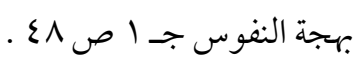

$$
\begin{aligned}
& \text { أربع رسائل في التصوف للإمام القشيري ص سه هـ }
\end{aligned}
$$




\section{موقف الحافظ ابن أبي جمرة من التصوف}

هي التزه عن أخلاق البهائم والشياطين ، والتحلية هي التخلق بأخلاق الروحانين ، فأخلاق البهائم : الاهتحام بالأكل والشرب و النكاح ، وأخلاق الشياطين : الحسد والمكر ، والخديعة ، والغش ، والكبر ، والغضب ، وغير ذلك . و أخلاق الروحانيين سلامة الصدر ، وسخاوة النفس ، وحسن الخلق ، و التو اضع ، و الحلم و التأني ، و السكينة ، و الطمأنينة وغير ذلك من العلوم ) (1). فالتحلي يأتي بعد التخلي ، ولا يكون مرة واحدة ، وليس على درجة واحدة ، فبداية ( على قدر التخلي يكون التحلي ). ودليله قوله المعراج : (فأتيت بطست من ذهب ملىع حكمة وإيهانا فشق من النحر إلى مراق البطن ثم غسل البطن بهاء زمزم ثم ملىع حكمة وإيهانا ) (r). يقول الحافظ ابن أبي جمرة : ( فيه دليل لأهل الصوفة في قولهم "لا يكون تحلي إلا بعد تخلي " ؛ لأنه لم يوضع الإيمان والحكمة في الباطن المباركة حتى شقت وغسلت وحينئذ ملئت ، فالشق والغسل هو التخلي ، وما ملئ به من الحكمة هو التحلي ، فعلى قدر التخلي يكون التحلي ) (r). والحديث ( دليل لأهل الصوفة في قولم : إن عمل المبتدئ كسب ، وعمل المنتهي ترك ؛ لأن

$$
\begin{aligned}
& \text { شرح صلاة القطب ابن مشيش ص الY r r . بتصرف . } \\
& \text { تقدم تخريجه . }
\end{aligned}
$$

بهجة النفوس جـ r ص INV ـ ـ وقد تقدم الكلام عن معنى هذه العبارة عند الحديث عن التخلي 


\section{موقف الحافظ ابن أبي جمرة من التصوف}

النبي كما مر الكلام عليه في حديث بدء الوحي، وكان تخليه هنا بالغسل وهو تنظيف المحل • وكذلك حال المبتدئ والمنتهي عندهم ، فالمبتدئ شأنه الكسب وهو الأخذ في الأعمال الصالحات وهي القوة ، والشدة والمنتهي شأنه النظر في الباطن وما يتعلق به من الشوائب فكل شيء يرى فيه شيئا ما من تعلق الشوائب تركه حتى يتنظف الباطن من الكدور ات ولا يبق فيه غير الله تعالى ) (1).

\section{كيفية التحلي وشروطه}

التحلي يكون بالترقي في المقامات السنية ، وفيه يتحلى العبد بالمقام ثم يترقى في نفس المقام ، ثم بعده المقام الأعلى حتى يتحلى العبد بالمقامات جميعها ؛ فيمتلئ بالمعاني والمعارف السامية .

والمقام هو ( ما يقوم بالعبد في الأوقات من أنواع المعاملات وصنوف المجاهدات ، فمتى أقيم العبد في شيء منها على التحام فهو مقامه حتى ينتقل فيه إلى مقام آخر )

وقد اختلف الصوفية في تحديد عدد المقامات فقيل ( إنها سبع مقامات ،

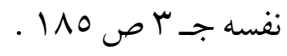

أربع رسائل في التصوف للإمام القشيري ص ه ع .. وانظر : الرسالة القشيرية ص بrا . 
موقف الحافظ ابن أبي جمرة من التصوف

وقيل تسع ، وقيل عشر مقامات ، وقيل أكثر من ذلك ) (1).

وقد عدها بتفصيل الإمام السهروردي في آداب المريدين ، وهي عنده "

الانتباه ، التوبة ، الإنابة ، الورع ، محاسبة النفس ، الإرادة ، الزهد ، الفقر ،

الصدق ، التصبر ، الصبر ، الرضا ، الإخلاص، التوكل على الله تعالى " (r).

\section{شروطالترقي}

اشترط الصوفية في الترقي إحكام المقام حتى يصح الترقي ؛ فإن من لا

$$
\text { توبة له لا تصح له الإنابة، ومن لا ورع له لا يصح له الزهد (r). }
$$

وقد تكلم الحافظ ابن أبي جمرة في هذا الشرط بشيء من التفصيل وألحق

معه شروطا تستنبط من فكره على النحو التالي :

\section{الشرطالأول : علو الهمة}

دليل هذا الشرط عند الحافظ الحديث الذي أخرجه الإمام البخاري عن

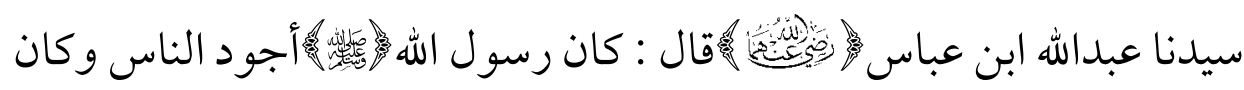
أجود ما يكون في رمضان حين يلقاه جبريل وكان يلقاه في كل ليلة من رمضان

/ / عبد المنعم البرلسي : الجهود الفكرية لتصحيح الطريق لدى الصوفية ص ابع ـ رسالة

$$
\text { دكتوراة . }
$$




\section{Ces 72}

\section{موقف الحافظ ابن أبي جمرة من التصوف}

فيدارسه القر آن فلرسول الله

وفيه يقول : ( في الحديث دليل لأهل السلوك الذين يقولون بالهمم تنال

المقامات لا بالأبدان ، وفيه من الفقه أنه من أراد زيادة الخير فلينظر في الأسباب المقوية للعزائم يأتيه العون ، ولا يأخذ الأمور من خارج ، وينظر إلى الأشياخ ليس إلا ، فإنه إن فعل لحقه الفتور والعجز الذي هو وصف البشرية ، ولهذا أشار همه هما واحدا وهو هم الآخرة ذهبت عنه أوصاف البشرية وطلبها لحظوظها وخفت عليه العبادة ، و جاءه العون من حيث لا يحتسب ) (r) ـ فعلو الهمة معين على الترقي إذ به تتعلق الممة بالمقام الأعلى فيستصغر العبد ما هو فيه لطلب

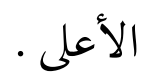

أخرجه الإمام البخاري: كتاب بدء الوحي. باب كيف كان بدء الوحي لرسول الله||]. جـ أ ص 7 .

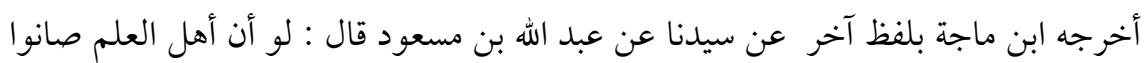

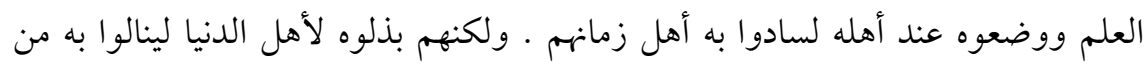

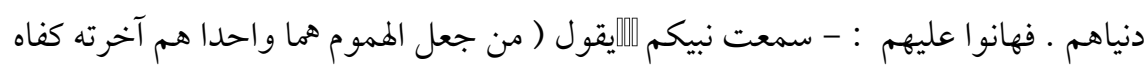

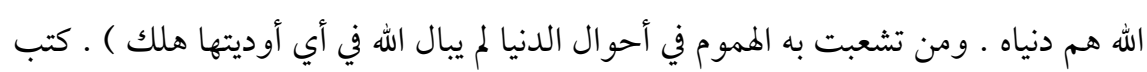
الإيمان ـ باب الانتفاع بالعلم والعمل به ـ جـ ال ص 90 ـ تحقيق : محمد فؤاد عبد الباقي ـ دار

$$
\text { الفكر -بيروت . }
$$




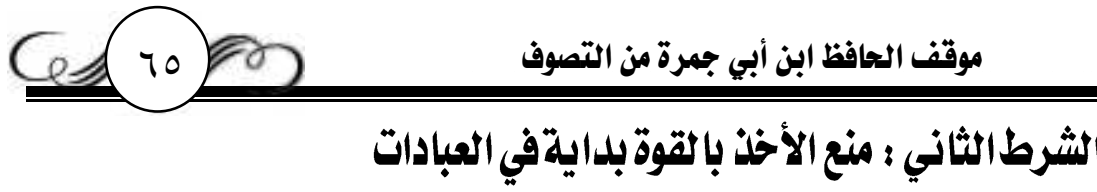

هذا شرط مقيد لما قبله فإن علو الهمة يجب ألا يكون دافعا للأخذ بالقوة

): في بدايات العبادات ، بل لابد أن يكون الترقي بالتدريج • ودليله قوله

إن الدين يسر ولن يشاد الدين أحد إلا غلبه فسددوا وقاربوا وأبشروا واستعينو ا بالغدوة والروحة وشيء من الدلجة )('.

يقول الحافظ ابن أبي جمرة : ( في هذا إشارة إلى التربية بالتدريج في

السلوك والترقي ، ومنع الأخذ بالقوة أولا في التعبدات من نوافل الليل والنهار وغير ذلك ؛ لأن من يأخذ بذلك في بداءة أمره يغلبه الدين بالضرورة لقلة الرياضة فيما أخذ بسبيله ، ومثل هذا ما روي " أن عمر ابن الخطاب

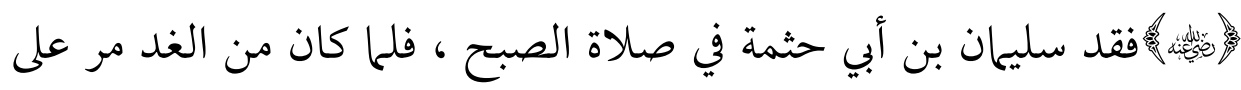
الشفاء أم سليان فقال لها : لم لم أر سليان في الصبح فقالت : إنه بات يصلي فغلبته عيناه ، فقال عمر : لأن أشهد صلاة الصبح في الجماعة أحب إلي من أن أقو ليلة " (r). فانظر كيف فضل حضور الصلاة في الجماعة على قيام الليل كله

أخرجه الإمام البخاري بسنده عن سيدنا أبي هريرة|||ل.كتاب الإيمان .باب إن الدين يسر جـ ا

ص صr

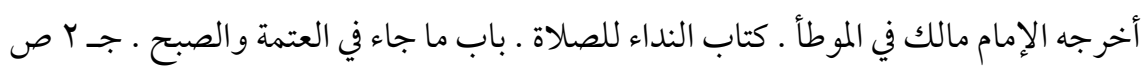

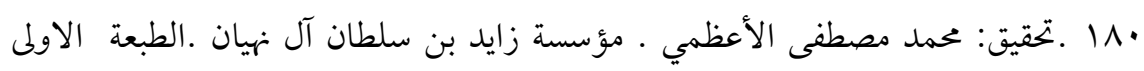

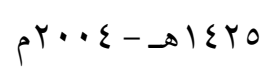




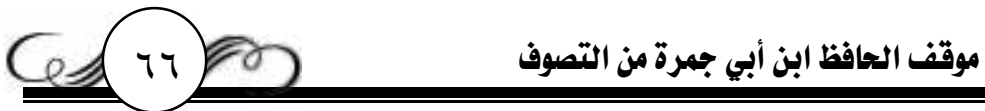

، مع أن قيام الليل فيه من المشقة ما هو معلوم لكن لما أن كان ذلك القيام كله من جنس المندوب وآل أمره إلى أن أوقع الخلل في فضل من فضائل

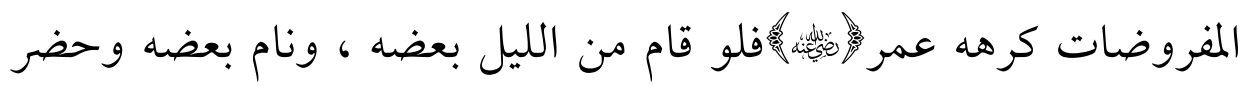
الصلاة في جماعة لكان من الآخذين بالكمال ولم يقع عليه بذلك غلبة في نقص فضيلة ولا غيرها ، فإذا أخذ المرء أولا نفسه بالرفق والرياضة في تعبداته حتى يصير ما أخذ من ذلك عادة كانت العبادة عليه يسيرة لا مشقة عليه فيها حتى يبلغ بها النهاية وهو كأنه لم يزد على نفسه شيئا ) (")

ولذا قال 算 الأخذ الكلي الذي تصلون به إلى المشادة فيغلبكم الدين ، وسددوا : أي ليكن جد كل شخص على ما تقتضيه بنيته وطاقته ومزاجه ، ومن هذا الباب راح

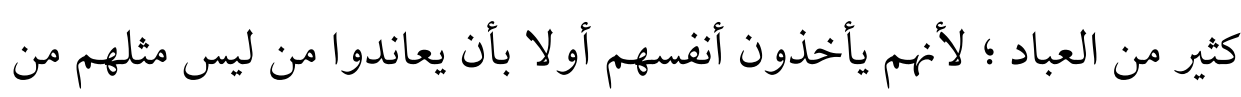
أهل النهايات فيأخذوا مأخذهم ، ويسلكوا مسلكهم فيقطع بهم في الحال عنهم ؛ لأنه قد يكون من أرادوا التشبه به أكثر قوة في بدنه منهم ، وأعدل مزاجا ، وأخذ نفسه أولا فيها هو بسبيله الآن بالتدريج في السلوك والترقي حتى صار له ما هو بسبيله من التعبد مزاجا، ولهذا قال يمن بن رزق (() الإمام

$$
\text { بهجة النفوس جـ ا ص Vo. }
$$

يمن بن رزق الزاهـد من أهل تطيلة يكنى أبا بكر و وكان أصل يمن بْن رزق من الثغر ، من قرية $=$ 


\section{ClV موقف الحافظ ابن أبي جمرة من التصوف}

في الطريقين : " حذار حذار أهل البدايات من أن تتشبهو أبهل النهايات فإن

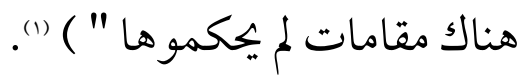

وتكملة هذا المعنى في قوله

من الدلجة " ( حيث يستحب لأهل السلوك أن تكون البداية أولا في الليل والنهار ركعتين ركعتين ثم يزيد على ذلك ما يشاء وبحسب النشاط ؛ لئلا يخلي نفسه من الاستعانة كما تقدم حتى يبلغ بالتدريج ما أمل ؛ لأن من أخذ من هذه الأوقات بقدر طاقته من العبادات ترقى إلى ما شاء من المراتب السنية ، ولا يدركه في ذلك تعب ، فإذا أخذ بذلك كان أبدا في الترقي بالزيادة تاركا للنقص حتى يبلغ بذلك إلى نهاية ما يقتضيه حال البشرية (r)(r).

\section{الشرطالثالث : الملداومة على الطاعاتوالمتابعة بينها.}

بعد الوصول لابد من المداومة حتى يجصل الترقي في المقامات

=

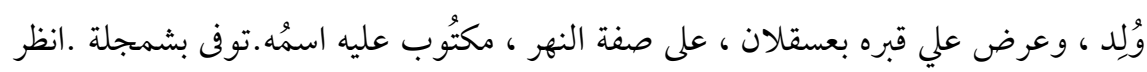

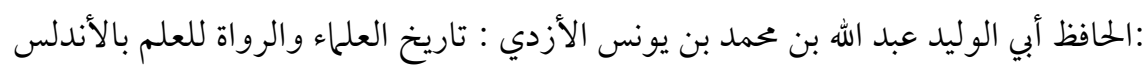

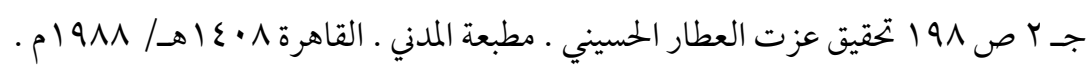

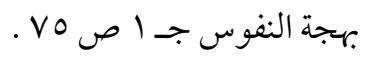

يقصد الحافظ بذلك أن آخر حال البشرية هو الولاية .

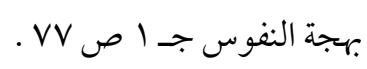




\section{موقف الحافظ ابن أبي جمرة من التصوف}

والعبادات ، فإن السالك لما علت همته ، ومنع أخذ نفسه بالقوة في البداية ، رزقه الله الطاعات وجب عليه المداومة عليها والمتابعة بينها ـ وشاهد ذلك قوله يحدث فيه تقول اللهم اغفر له اللهم ارحمه ) (1).

يقول الحافظ ابن أبي جمرة: ( في الحديث دليل لأهل الصوفة الذين يقولون : إن الطاعة إذا لم تتبعها طاعة أخرى فهي مدخولة ، يؤخذ ذلك من

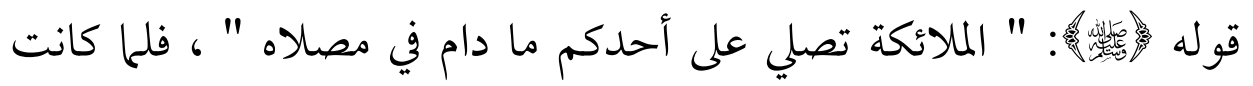
صلاته أو بعضها مقبولة تبعها خير آخر ، وهو جلوسه حتى استغفرت له له الملائكة فكان خير اتبعه خير ) (1)

\section{الشرطالرابع : الأدبشرطفي الترقي}

الأدب هو ركن الترقي وعماده الذي لا يوجد إلا به ، فالأدب في المقام

وإحكامه وسيلة الوصول و الترقي ، وليس ذلك في مقام دون مقام بل هو في جميعها .

ولأجل هذا المعنى يقول أهل الصوفة : من نال مقاما فدام عليه بأدبه

أخرجه الإمام البخاري بسنده عن أبي هريرة||لكتاب أبواب المساجد ـ باب الحدث في المسجد

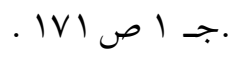

$$
\begin{aligned}
& \text { بهجة النفوس جـ اص ص الص 19 19r 19 . }
\end{aligned}
$$




\section{Ces 79}

\section{موقف الحافظ ابن أبي جمرة من التصوف}

ترقى إلى ما هو أعلى منه ، فمن دام على التأدب في المقام الذي أقيم فيه ترقى في المقامات حيث شاء الله تعالى عدا مقام النبوة التي لا مشاركة للغير فيها بعد النبي إلى مقام النبوة أبدا ، وذلك لأن النبوة منحة واصطفاء من الله تعالى ، وليست تنال بكثرة عبادة أو سمو في مقامات الوصل و القرب (r) . وإذا أتم العبد ذلك كله بأن سدد في العبادة وقارب ، وداوم على

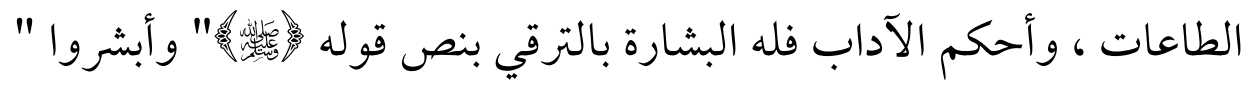
الذي يتخذه الحافظ ابن أبي همة شاهدا لأهل السلوك في قولم : ( من بلغ بعض المنازل فدام عليه بأدبه فإنه يترقى إلى ما هو أعلى منه ، فها دام على هذه

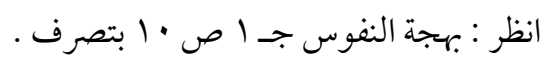

عقيدة أهل السنة أن النبوة غير مكتسبة بل هي فضل من الله تعالى ، يقول الإمام اللقاني في

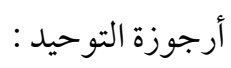

$$
\begin{aligned}
& \text { ولم تكن نبوة مكتسبة **** ولو رقى في الخير أعلى عقبة } \\
& \text { بل ذاك فضل الله يؤتيه من ق**** يشاء جل الله واهب المنن }
\end{aligned}
$$

يقول الإمام البيجوري :(قوله: ولم تكن نبوة مكتسبة) أي لا يكتسبها العبد بمباشرة أسباب خخصوصة كملازمة الخلوة والعبادة وتناول الحلال كما زعمت الفلاسفة ؛ فالذي ذهب إليه المسلمون جميعاً أن النبوة خصيصة من الله تعالى لا يبلغ العبد أن يكتسبها. ويفسرونها

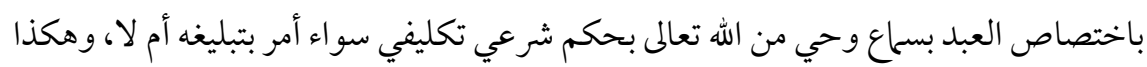

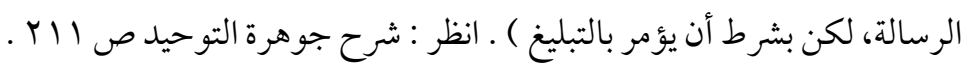




\section{موقف الحافظ ابن أبي جمرة من التصوف}

الحال لايزال في ترق حتى يبلغ غاية المنازل الرفيعة عملا منهم على مقتضى

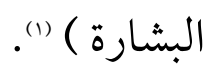

\section{الشرطالخامس : استصحابالعمل وترك الالتفات}

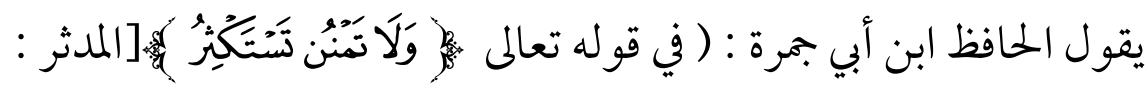

T]دليل لأهل الصفة في قولهم باستصحاب العمل وترك الالتفات ودوام الإقبال والحضور ؛ لأن النظر إلى كثرة العمل يحدث الكسل ، فكيف به إذا كان النظر لغير العمل ؟ ، ومنه قولهم : الوقت سيف ، يريدون به : اقطع الوقت بالعمل لئلا يقطعك بالتسويف ؛ ولأن الالتفات بالحظوظ وكثرة العمل وغير ذلك هلاك ، و السالك إذا التفت إلى الهلاك كان هالكا ) (r).

و أعظم أنواع هذا الالتفات ما كان في محل القرب و المناجاة وهو الصلاة ، فلا يلتفت العبد إلى شيء آخر غير ربه سبحانه وتعالى ، فلا يلتفت إلى شيطان

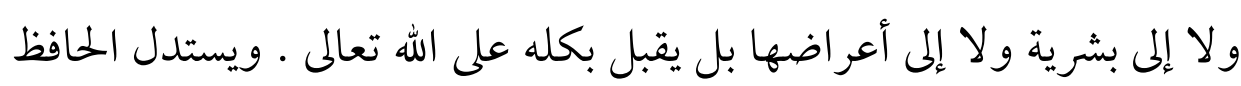

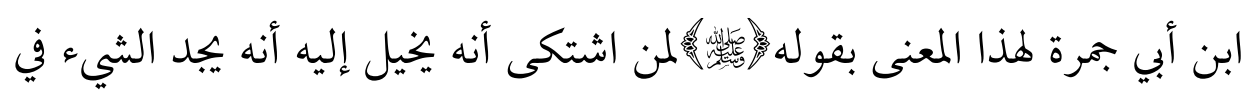
الصلاة فقال : ( لا يتقل أو لا ينصرف حتى يسمع صوتا أو يجد ريحا ) ). (r).

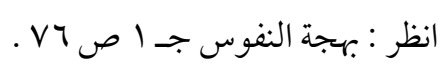

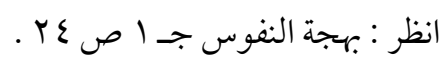




\section{موقف الحافظ ابن أبي جمرة من التصوف}

فيقول : ( هنا إشارة لطيفة وذلك أنه لما كان العبد قد توجه إلى الحضرة العلية فلا يلتفت إلى البشرية وعوارضها فإنه خال في الحال فإن جاءه أمر متحقق فهو حكم رباني واجب الامتثال له ) (1). ( وفيه من الإشارة لأهل القلوب ألا يلتفتو ا إلى الشكوك ولا إلى العوارض لا قليلا ولا كثيرا ) (r).

وألا يلتفتوا إلى الشيطان ووسوسته ، وقد حذري إل الحديث الذي أخرجه الإمام البخاري بسنده عن سيدنا أبي هريرة قال النبي فإذا ثوب بها أدبر فإذا قضي أقبل حتى يخطر بين الإنسان وقلبه فيقول اذكر كذا وكذا حتى لا يدري أثلاثا صلى أم أربعا فإذا لم يدر ثلاثا صلى أو أربعا سجد سجدتي السهو (r) (r) يقول الحافظ ابن أبي جمرة: ( فيه دليل لأهل الصوفة لأنهم أخذو بدوام الاشتغال وعدم الالتفات إلى حديث النفس وغيرها ؛ لأن هذا المصلي ما طر أ عليه النسيان إلا من جهة التفاته إلى حديث العدو ، وبها ذكره به وميله إليه ) (".

$$
\begin{aligned}
& \text { بهجة النفوس جـ ا ص } 10 \text {. }
\end{aligned}
$$

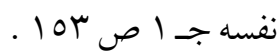

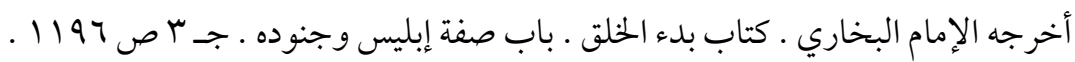

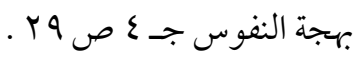


موقف الحافظ ابن أبي جمرة من التصوف

وبعد هذه النظرة المعرفية في موقف الحافظ ابن أبي جمرة من التصوف

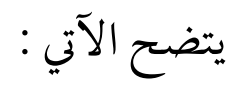

1 - من خلال قراءة الحافظ ابن أبي جمرة في التصوف الإسلامي قراءة بجملة يظهر أنه اتبع في بيان المسائل المنهج التالي :

أ - بيان المسألة المرادة في السنة الشريفة والتدليل على مشروعيتها إجمالا . ب - بيان حسن عمل الصوفية المتشرعين في هذه المسألة ، وأن أحاديث

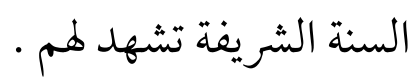
جـ - بيان الشروط الواجب توافرها في المسألة المراد بيانها حتى تصبح على السنة .

ץ- أكد الحافظ ابن أبي جمرة مرارا على وجوب التمسك بالكتاب والسنة ،

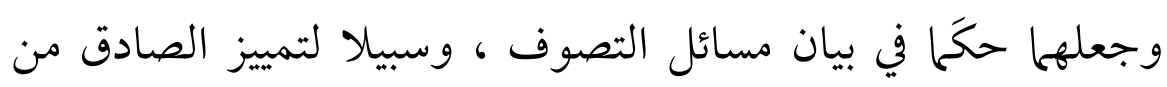
المدعي • و لا عجب في ذلك فالحافظ شيخ في السنة وأحد المدافعين عنها . r- فرق الحافظ ابن أبي جمرة بين الصادقين والأدعياء في التصوف باستخدام أسماء مختلفة تدل على كل طائفة دون الأخرى .

ع- اهتم الحافظ ابن أبي جمرة بييان حسن طريقة أهل التصوف في التربية ، 


\section{موقف الحافظ ابن أبي جمرة من التصوف}

وأكثر من الاستدلال على ذلك من السنة المطهرة ، مع التأكيد على ضرورة

$$
\text { كو نها على الكتاب و السنة . }
$$

0- - وافق الحافظ ابن أبي جمرة المحققين من مشايخ التصوف في نقد الأقوال الشنيعة المنسوبة للتصوف وليست منه ، فوافق نقده نقدهم ، وذلك راجع لوحدة المسلك ووحدة الغاية في النقد .

7- أكد الحافظ ابن أبي جمرة على ضرورة سبق التخلي على التحلي حتى مع كونه غير مكتسبا ، و أنه على قدر التخلي يكون التحلي .

V- تكلم الحافظ ابن أبي جمرة عن الخو اطر وأقسامها ، وأنه لابد من التسلح بميز ان الكتاب والسنة ، حتى يستطيع المريد تمييز هذه الخو اطر ، فكل خاطر لا يشهد له الكتاب والسنة فهو خاطر نفسي أو شيطاني وإلا فهو رباني أو ملكي

^- الترقي في المقامات السنية هو غاية السالك إلى الله تعالى ، والحافظ ابن أبي جمرة يرى أنه لابد في الترقي من شروط حتى يؤتي ثمرته ، وأهم هذه الشروط هو الأدب فبالأدب تنال المقامات . وفي النهاية أسأل الله تعالى التوفيق والسداد والقبول ، وأن يجعل هذا العمل خالصا لوجهه الكريم • وصلى الله على سيدنا حمد وعلى آله وصحبه وسلم • وسلام على المرسلين والحمد لله رب العالمين . 
أهم المراجع من التصوف

$$
\text { ץ- القرآن الكنة النبوية }
$$

ץ- : آداب المريدين : أبو النجيب السهروردي تحقيق : الدكتور / عاصم

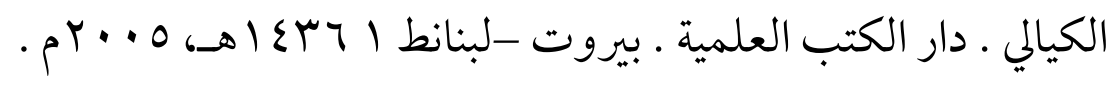
ع- أربع رسائل في التصوف للقشيري ـ د/ قاسم السامر ائي. المجمع العلمي

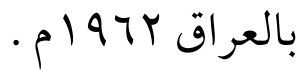

ه- الأعلام : خير الدين الزركلي · دار العلم للملايين -بيروت-لبنانط

$$
\cdot r \cdot r / 10
$$

7- الاعتصام : الإمام الشاطبي • تحقيق: سليم بن عيد الهلالي .دار ابن عفان،

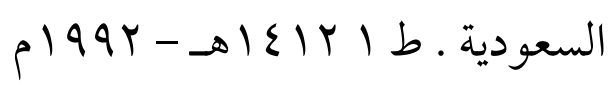

V - التصوف الإسلامي في ميزان الكتاب والسنة : الأستاذ الدكتور / عبداله

$$
\text { الشاذلي : مكتبة الأزهر الحديثة -طنطا ا +. بم . }
$$

1- التعرف لمذهب أهل التصوف : أبو نصر الكلاباذي. تحقيق أرثر جون

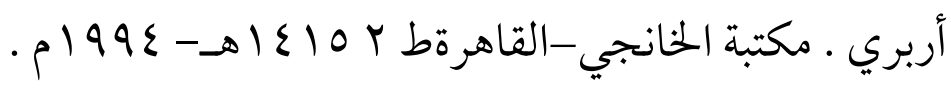

9- التعريفات : الجرجاني ـ تحقيق : إبراهيم الإبياري ـ دار الكتاب العربي .

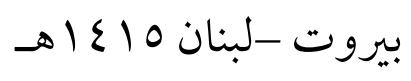

• 1 - الجهود الفكرية لتصحيح الطريق لدى الصوفية د/ عبدالمنعم البرلسي . 
Clvo موقف الحافظ ابن أبي جمرة من التصوف

$$
\text { رسالة دكتوراة . }
$$

الا - الرسائل والمسائل : الإمام ابن تيمية ـ تحقيق :السيد محمد رشيد رضا

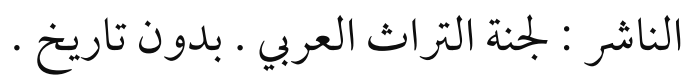

rا - الرسالة القشيرية : الإمام أبو القاسم القشيري ـ تحقيق الإمام الأكبر الأستاذ الدكتور / عبدالحليم محمود ، الدكتور محمود بن الشريف .

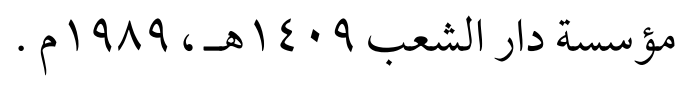

با - الزهد الكبير للبيهقي • تحقيق الشيخ عامر أحمد حيدر ـ مؤسسة الكتب

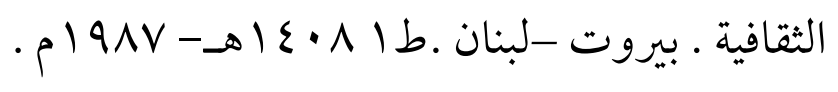

عا - العبر في خبر من غبر : الحافظ الذهبي . تحقيق : أبو هاجر محمد السعيد

$$
\text { بن بسيوني زغلول دار الكتب العلمية -بيروت . }
$$

10 الغنية لطالبي طريق الحق الشيخ عبدالقادر الجيلاني .تحقيق : أبو

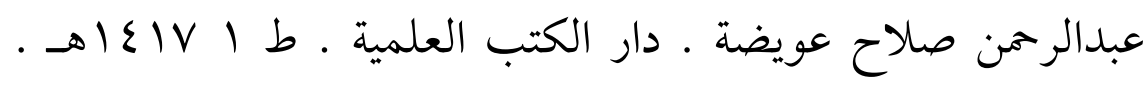
- p $199 \mathrm{~V}$

1 - الفتح الرباني : الشيخ عبدالقادر الجيلاني ـ قدم له : خليل الميسي . دار

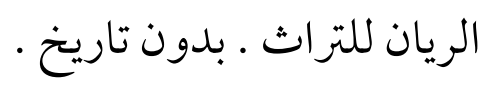

IV - الكليات : أبو البقاء الفكومي. تحقيق عدنان درويش -محمدالمصري

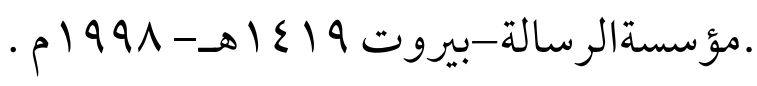

11 - اللمع : السراج الطوسي .تحقيق : الإمام الأكبر الأستاذ الدكتور / 


\section{موقف الحافظ ابن أبي جمرة من التصوف}

عبدالحليم محمود ، طه عبدالباقي سرور ـ دار الكتب الحديثة بمصر

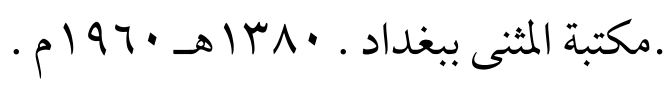

19 - المقدمة في التصوف : أبو عبدالرحمن السلمي ـ تحقيق د/ يوسف زيدان .

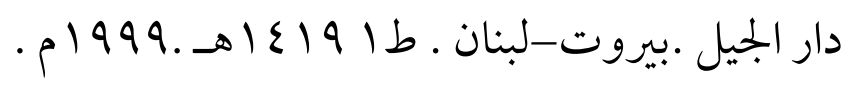

• ץ- تبصير المنتبه بتحرير المشتبه ـ الحافظ ابن حجر العسقلاني :.تحقيق : محمد علي النجار -عليمحمدالبجاوي ـ دار الكتبالعلمية .بيروت-لبنان

ا آ- تقريب التهذيب ـ الحافظ ابن حجر العسقلاني. تحقيق / محمد عوامة

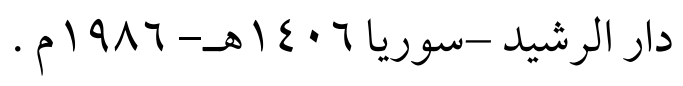

YYT- تفسير التحرير والتنوير . الطاهر بن عاشور .دار سحنون للنشر

$$
\text { والتوزيع - تونس - 199V م موتري }
$$

بץ- تاريخ العلماء والرواة للعلم بالأندلس .الحافظ أبي الوليد عبد الله بن محمد بن يونس الأزدي :تحقيق عزت العطار الحسيني ـ مطبعة المدني .

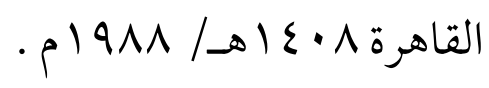

ع ץ- حسن المحاضرة في تاريخ مصر والقاهرة ـ الإمام السيوطي . ط ا دار

$$
\text { إحياء الكتب العربية . عيسى البابي الحلبي -القاهرة . }
$$

0Y - حاشية على خختصر ابن أبي جمرة ـ الشيخ الشنواني ـ مطبعة مصطفى البابي

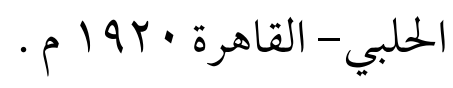




\section{ClVV موقف الحافظ ابن أبي جمرة من التصوف}

جr- داعي الفلاح : الشيخ / عممد المرصفي :. تحقيق : د/ عاصم الكيالي .

ملحق بكتاب آداب المريدين للسهروردي ـ دار الكتب العلمية ـ بيروت

$$
\text { - لبنانط | }
$$

V V - دراسات في التصوف الإسلامي :أ.د/ فتحي الزغبي . مكتب الأشول

$$
\text { للطباعة . طنطا -مصر . 11 أهـ . 1911 م . }
$$

^ץ - سنن ابن ماجة ـ تحقيق د/ محمد فؤاد عبدالباقي • دار الفكر بيروت -

$$
\text { لبنان }
$$

و r - سنن الترمذي ـ تحقيق الشيخ أحمد شاكر وآخرون . دار إحياء التراث

$$
\text { العربي • بيروت -لبنان . }
$$

• ب- شرح جوهرة التوحيد ـ الإمام البيجوري . تحقيق الأستاذ الدكتور /

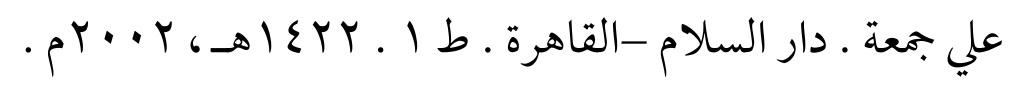

اس- شرح صلاة القطب ابن مشيش : الشيخ أحمد بن عجيبة الحسني. تحقيق : العمراني الخالدي عبدالسلام ـ دار الرشاد الحديثة ـ الدار البيضاء -

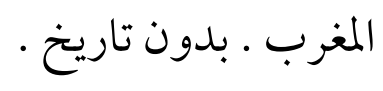

r ب- شعب الإيمان ـ الإمام البيهقي ـ تحقيق محمد السيد بسيوني زغلول . دار

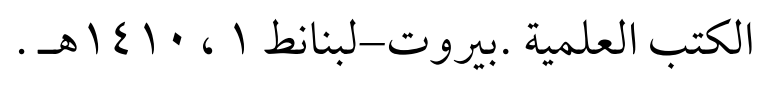

سب- صحيح البخاري . تحقيق : د. مصطفى ديب البغا. دار ابن كثير ، اليمامة

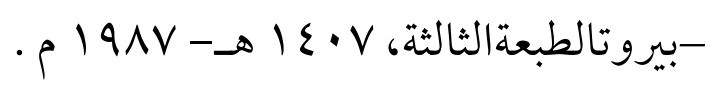




\section{موقف الحافظ ابن أبي جمرة من التصوف}

ع ب- صحيح مسلم .دار الجيل بيروت دار الأفاق الجلديدة - بيروت-لبنان . هب- طبقات الأولياء : ابن الملقن . تحقيت نور الدين شريبة . مكتبة

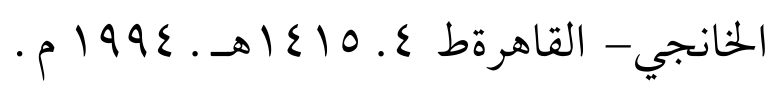

جr- طبقات الصوفية : أبو عبدالرحمن السلمي. تحقيق : مصطفى عبدالقادر عطا ـ دار الكتب العلمية . بيروت -لبنان . ط 1919 ع 1هـ 1991 م . V- قضية التصوف : المنقذ من الضلال ـ الإمام الأكبر الدكتور / عبدالحليم حمود ـ دار المعارف الطبعة الثالثة . ^ץ- قواعد التصوف: الشيخ زروق الفاسي. تحقيق : عبدالمجيد خيالي . دار

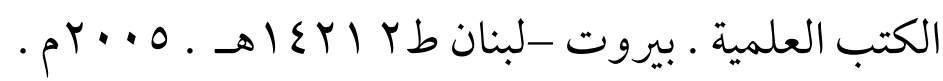
وب- كشف المحجوب :الهجويري ـ دراسة وترجمة وتعليق الدكتورة / إسعاد

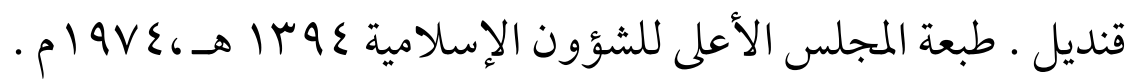
• ع - كشف الظنون عن أسامي الكتب والفنون : حاجي خليفة ـ مكتبة المثنى

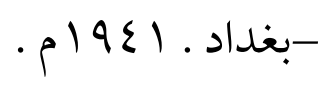

اع - لسان العرب : ابن منظور ـ دار صادر بيروت -لبنان . rع - معجم المؤلفين : عمر كحالة . الناشر مكتبة المثنى - بيروت دار إحياء

$$
\text { التراث العربي بيروت . }
$$

بع - معراج التشوف إلى حقائق التصوف : الشيخ أحمد بن عجيبة ـ تحقيق د / عبدالمجيد خيالي . مركز التراث الثقافي المغربي - الدار البيضاء - 


\section{Ce) موقف الحافظ ابن أبي جمرة من التصوف}

$$
\text { المغرب · بدون تاريخ · }
$$

ع - مفاتيح الغيب ـ الإمام الفخر الرازي. دار الكتب العلمية - بيروت-

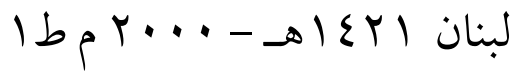

م - مفتاح الفلاح ومصباح الأرواح : الإمام / ابن عطاء الله السكندري .

تحقيق : عحمد عبد السلام إبراهيم. دار الكتب العلمية . بيروت -لبنان .

Tع - موطأ الإمام مالك .تحقيق: محمد مصطفى الأعظمي . مؤسسة زايد بن

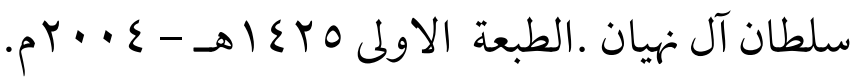

ع V بن الفضل ابن مامين. دار الفكر بيروت -لبنان . بدون تاريخ • 


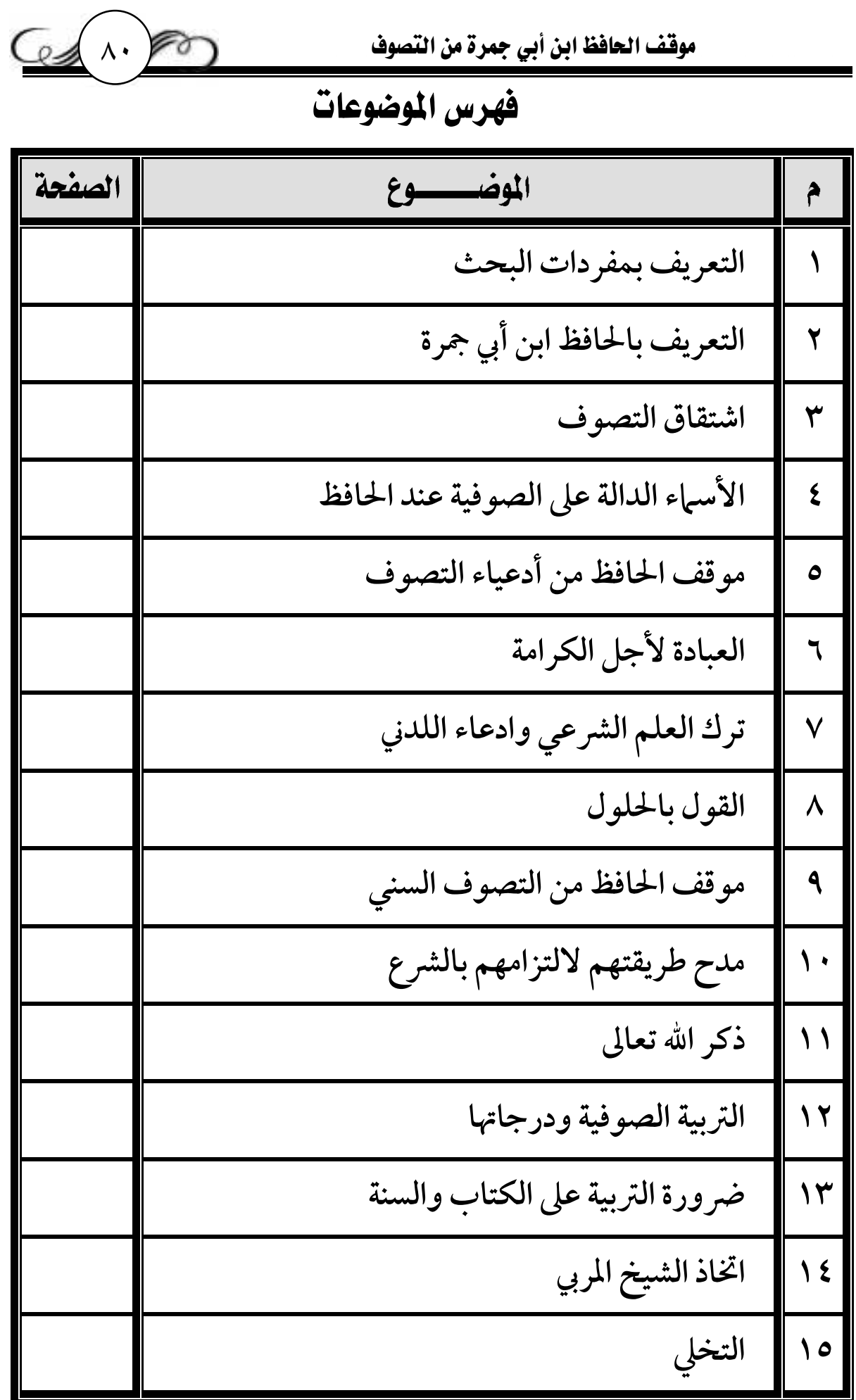




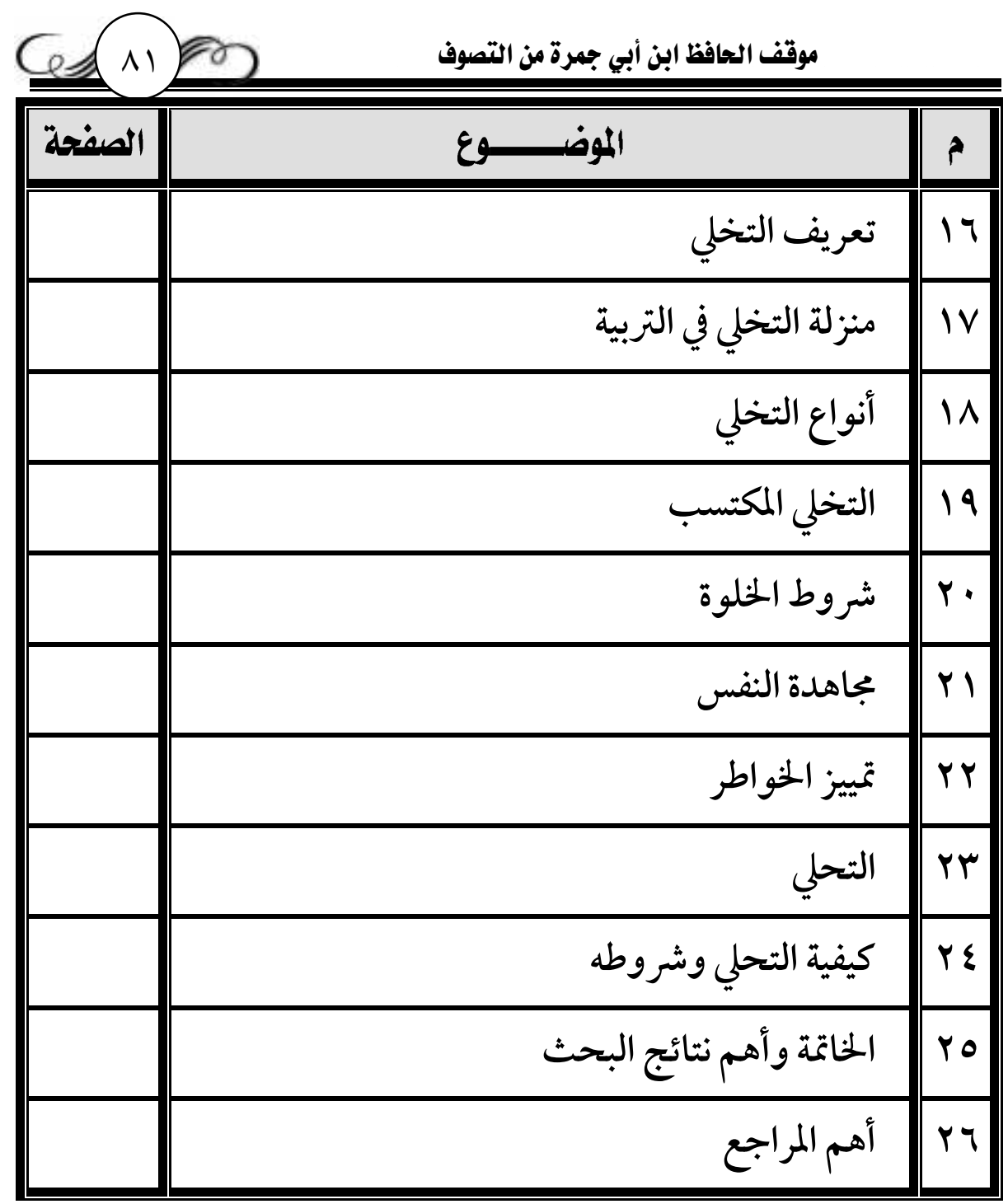

